\title{
Heavy Metals in Water and Surface Sediments of the Fenghe River Basin, China: Assessment and Source Analysis
}

\section{Pingping Luo}

Key Laboratory of Subsurface Hydrology and Ecological Effects in Arid Region, Ministry of Education, Chang'an University, Xi'an, China

Chengyi Xu ( $\sim 2019129033 @ c h d . e d u . c n)$

School of Water and Environment, Chang'an University, Xi'an, China https://orcid.org/0000-0002-66586521

\section{Shuxin Kang}

School of Water and Environment, Chang'an University, Xi'an, China

\section{Aidi Huo}

Key Laboratory of Subsurface Hydrology and Ecological Effects in Arid Region, Ministry of Education, Chang'an University, Xi'an, China

\section{Jiqiang Lyu}

Key Laboratory of Subsurface Hydrology and Ecological Effects in Arid Region, Ministry of Education, Chang'an University, Xi'an, China

\section{Meimei Zhou}

Key Laboratory of Subsurface Hydrology and Ecological Effects in Arid Region, Ministry of Education, Chang'an University, Xi'an, China

\section{Daniel Nover}

School of Engineering, University of California - Merced, 5200 Lake Rd., Merced, CA, 95343, USA

\section{Research Article}

Keywords: Fenghe River Basin, heavy metal, surface water and sediment, assessment, source pollution

Posted Date: February 8th, 2021

DOl: https://doi.org/10.21203/rs.3.rs-160454/v1

License: (c) (i) This work is licensed under a Creative Commons Attribution 4.0 International License. Read Full License 
Heavy metals in water and surface sediments of the Fenghe River Basin, China: Assessment and Source Analysis

1 Pingping Luo ${ }^{1,2}$, Chengyi $\mathrm{Xu}^{2,}{ }^{*}$, Shuxin Kang ${ }^{1,2}$, Aidi Huo ${ }^{1,2}$, Jiqiang Lyu ${ }^{1,2}$, Meimei Zhou ${ }^{1,2}$,

2 Daniel Nover ${ }^{3}$

3

4 1. Key Laboratory of Subsurface Hydrology and Ecological Effects in Arid Region, Ministry of

5 Education, Chang'an University, Xi'an, China

6 2. School of Water and Environment, Chang'an University, Xi'an, China

7 3. School of Engineering, University of California - Merced, 5200 Lake Rd., Merced, CA, 95343,

8 USA

9

10

11 *Corresponding author : Chengyi Xu (2019129033@chd.edu.cn)

12 


\section{Abstract}

This paper combines environmental science, inorganic chemistry, water quality monitoring and other disciplines, and uses several representative evaluation methods (WQI, Pn, I-geo, RI) for heavy metals in water and sediments. A preliminary assessment and source analysis of heavy metals $(\mathrm{Cd}, \mathrm{Cr}, \mathrm{Fe}, \mathrm{Mn}, \mathrm{Zn}, \mathrm{Cr}, \mathrm{Ti}, \mathrm{Ni}, \mathrm{Cu}$, $\mathrm{As}, \mathrm{Pb}, \mathrm{Sr}$ ) in water and surface sediments of the Fenghe River Basin, Shannxi Province, China was carried out in this study. Results indicate that most of the heavy metals in water are below national water quality standards. Exceptions include Mn, which exceeds national tertiary standards and $\mathrm{Cr}$, which exceeds national drinking water standards. Most heavy metals in the sediments exceed the environmental standard values except Ni. Water quality index (WQI) and Nemero index (Pn) showed the same trend in contamination levels of sampling sites. According to the Geological Accumulation Index method (I-geo) and the Potential Ecological Risk Index method (RI), high concentrations of $\mathrm{Cd}$ poses a high ecological risk in some sampling locations. Pearson Correlation Analysis (CA), Hierarchical Clustering Analysis (HCA), Principal Component Analysis (PCA) and Positive Matrix Factorization (PMF) models are used to explore the relationships and sources of heavy metals. In general, upstream sources are similar, and middle and lower reaches are easily clustered into a large category except for some specific sampling points. For example, metals in sampling site FHK mainly come from surrounding residents and farms and heavy metals attributes in sampling site SLQ relate to the fact that municipal sewage is collected and treated. The factors or sources of heavy metals in water and sediment 


\section{.}

are revealed in detail through PMF models. In the water, the average contribution rate of these four source factors for heavy metals is $36.8 \%, 11.7 \%, 9.4 \%$ and $42.0 \%$, while the average proportion of these four factors for heavy metals in sediment is $8.0 \%$, $29.2 \%, 23.9 \%$ and $38.9 \%$ respectively. Results show that the main sources of pollution in the region are urban construction and transportation, electronics industry, machinery manufacturing, tourism and agriculture. These sectors should therefore be given sufficient attention in the prevention and management of heavy metal pollution. Keywords: Fenghe River Basin, heavy metal, surface water and sediment, assessment, source pollution 


\section{Introduction}

Heavy metals, as common pollutants in the water environment, are toxic, persistent and bio-accumulative (Pekey et al. 2004). Excessive doses of heavy metals threaten the environment and humans through direct exposure and food chain enrichment (Zhang et al. 2016; Lin et al. 2016). Sediments are sources and sinks of heavy metals.

Factors such as temperature, $\mathrm{pH}$, dissolved oxygen, redox potential and electrical conductivity control the release of heavy metals from sediments, causing secondary pollution to water quality (Lin and Chen 1998; Bertin and Bourgm 1995; Li et al. 2014; Ndimele 2012). Heavy metal pollution is caused by natural factors, such as weathering and riverbed erosion, and human activities, especially mining, mechatronic industries, urban construction, urban flood, urban transportation, and agriculture (Mohamed 2007; Mu et al. 2020; Ke et al. 2015; Zhuang and Gao 2015). Comprehensive analysis of status, potential risks and sources of heavy metals in water and sediments is therefore essential for environmental control and management.

Heavy metal pollution in rivers has aroused widespread concern due to the rapid development of society ( $\mathrm{Li}$ and Zhang 2010). By the mid-19th century, about $40 \%$ of Britain's rivers and lakes had been polluted by human behavior ( $\mathrm{Li}$ et al. 2014). Approximately $85 \%$ of heavy metals are ultimately enriched in surface sediments on a global scale (Zahra et al. 2014). In Europe, North America, Africa and Asia, heavy metal pollution has been studied extensively, especially the rivers Rhine and Meuse in Western Europe (Wijnhoven et al. 2006), the Danube River (Sunjog et al. 2012), the Mississippi River in America (Grabowski et al. 2001), the Nile River in Egypt 
(Elbouraie et al. 2010), the Soan in Pakistan (NAZEER et al. 2014), the Subarnarekha River in India (Giri and Singh 2014), the Yellow River (Sun et al. 2016) and the Yangtze Rivers (Guo and Yang 2016) in China. In China, about 6 of the 21 major cities along the Yangtze River (Panzhihua, Yichang, Nanjing, Wuhan, Shanghai, Chongqing) have a pollution rate of heavy metals of 65\% (Zhang and Shu 2010).

Faced with such serious heavy metal pollution, a great deal of research has assessed aspects of contamination, such as migration and transformation processes, bioaccumulation, and toxicity (Pandey and Bhattacharya 2016; Ogendi et al. 2010; Simpson and Spadaro 2016). However, such studies require complex laboratory analysis which affect data accuracy and precision, are time intensive, and are inapplicable at large scales. The total concentration of heavy metals can be used to evaluate the status of heavy metal pollution, potential ecological risks and sources (Villanueva and Ibarra 2016). In addition to comparison with national water quality standards, evaluation methods for heavy metals in water are well-established and include the single factor water quality index method $(\mathrm{Pi})$ and multi-factor Water Quality Index method (WQI) (Cheng and Dan 2011; Parparov et al. 1992), and the Nemero index method (Pn) (Tianxiang et al. 2018). Similarly, there are many methods for evaluating heavy metals in sediments, including representative methods such as the Enrichment Factor method (EF) (Ergin et al. 1991), the Geological Accumulation Index method (I-geo) (Muller 1969), the Pollution Load Index method (PLI) (Angulo 1996), the Potential Ecological Risk Index method (RI) (Hakanson 1980) and the Sediment Quality Guidelines (SQG) (Macdonald et al. 2000). The Composite Element 
Index has a cooperativity effect and can comprehensively evaluate regional pollution status and potential risks. Thus, WQI, Pn, I-geo, RI were selected for this study. In the source analysis of heavy metals, Correlation Analysis (CA) is used to determine significant correlations between heavy metals through the correlation coefficient (Zhang et al. 2015). The greater absolute value of the correlation indicates a higher correlation between the two variables. Hierarchical Cluster Analysis (HCA) is based on the degree of similarity between variables, which is classified into categories (Facchinelli et al. 2001). Principal Component Analysis (PCA) reduces dimensionality in data to uncover trends (Kaidao et al. 2012). CA, HCA, and PCA can be used in combination to assess contaminant sources (Comero et al. 2011). However, the data required by software (SPSS) is sensitive and needs to be standardized (Pornsawai et al. 2013). The Positive Matrix Factorization (PMF) model (Anttila et al. $1995)$ is applied to study the contribution rate of each source more accurately and quantitatively. An advanced statistical method, PMF uses the least square method to estimate each value and analyze the uncertainty of each value. Although this model has been widely used in atmosphere studies (Jaeckels et al. 2007; Saraga et al. 2010; Yuan et al. 2012), application to pollution in water and sediments is rare.

Representative sampling points were selected to systematically study the heavy metal pollution in the Fenghe River Basin (FRB). The main goals of this study are (1) to describe the physical and chemical parameters and the concentration of heavy metals in water and surface sediments, (2) to comprehensively evaluate the pollution status of heavy metals in the water through the comprehensive Water Quality Index 
114

(WQI) and the Nemero Index (Pn), as well as the accumulation status and potential risks of heavy metals in sediments through the Geological accumulation Index (I-geo) and Potential Risk Index (RI) methodology, and (3) to qualitatively and quantitatively analyze the potential sources and contribution rates of heavy metal pollution by multivariate statistical analysis and the Positive Matrix Factorization (PMF) model.

\section{Materials and methods}

\subsection{Study area and sample collection}

As the first tributary of the south bank of the Wei River, the largest tributary of the Yellow River, the Fenghe River has a total length of $78 \mathrm{~km}$ and a watershed area of 1460km (Huaien et al. 2016). Its main tributaries include the Taipingyu, Fengyu, Gaoguanyu and the Yu River. Urban expansion and population growth have led to the implementation of the Hei River Water Diversion Project (Zhang et al. 2018; Wang and Tang 2012). As a result of upstream tourism, the construction of towns in the middle and lower reaches and industrial development have led to deterioration of water quality and ecology in the Fenghe River (Zhang et al. 2014).

Eight monitoring stations were investigated in the FRB: Fengyu (FY), Gaoguanyu (GGY), Taipingyu (TPY), Yurufeng (YRF), Fenghekou (FHK), Qinduzhen (QDZ), Yanjiaqu (YJQ), and Sanliqiao (SLQ). The layout of sampling points in the study area is given in Fig. 1. Monitoring stations cover representative control sections of hydrological monitoring stations and major tributary intersections from upstream to downstream. As three stations consist of sand and gravel, sediment 
samples were collected from five sampling locations of the Fenghe River in August, 2018. Water samples were collected from eight sampling locations in October and December 2018. We use the average concentration of heavy metals in water from two months.

\subsection{Sample collection and analysis}

In this study, water (USEPA 2013) and sediment (USEPA 2014) methods were used to collect samples. An YSI multi-parameter water quality analyzer (Germany) analyzed the physicochemical properties (temperature $\left({ }^{\circ} \mathrm{C}\right), \mathrm{pH}$, dissolved oxygen (DO), redox potential (ORP), electrical conductivity (EC)) of water. Samples (500 ml) were collected with polyethylene plastic bottles and sealed, and then brought back to the laboratory under $4{ }^{\circ} \mathrm{C}$. Water samples were filtered through a 0.45 um filter membrane and put in a $10 \mathrm{ml}$ centrifuge tube. The water samples were centrifuged using a low-speed centrifuge for $10 \mathrm{~min}$ under $3500 \mathrm{r} / \mathrm{min}$, and after $2 \% \mathrm{HNO}_{3}$ was added and refrigerated for preservation under $4{ }^{\circ} \mathrm{C}$. Surface sediment samples were sealed in polythene bags and returned to the laboratory. Samples were put in an oven at $105{ }^{\circ} \mathrm{C}$ for $12 \mathrm{~h}$ after natural drying, lightly crushed, sieved through 200-mesh nylon sieve and sealed in a polyethylene bag.

Pretreatment of sediment samples: The 50mg samples were weighed and placed

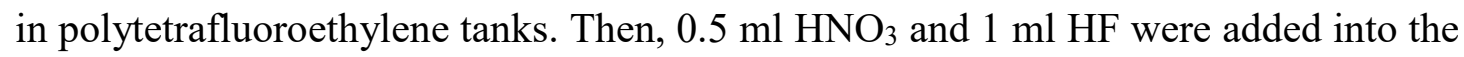
tanks and the samples were put on an electric heating plate for $145^{\circ} \mathrm{C}$ to remove silicon until the samples were dry. In addition, $1 \mathrm{ml} \mathrm{HNO}_{3}$ and $1 \mathrm{ml} \mathrm{HF}$ were continuously added into the tanks for $5 \mathrm{~h}$ under $145^{\circ} \mathrm{C}$. The treated samples were 
cooled to room temperature overnight and then steamed for $40 \mathrm{~min}$. A few drops of $\mathrm{H}_{2} \mathrm{O}_{2}$ were added to remove the organic matter and $1 \mathrm{ml} \mathrm{HNO}$ was added to steam. Finally, $2.5 \mathrm{ml} 40 \% \mathrm{HNO}_{3}$ were added into the samples for $4 \mathrm{~h}$, and then the samples were fixed to $50 \mathrm{ml}$ with $40 \% \mathrm{HNO}_{3}$. Total heavy metal content in the treated samples was determined by Inductively Coupled Plasma Mass Spectrometer (ICP-MS).

All reagents used in the experiment were analytical reagents. Calibration curves were determined with correlation coefficients in the range of 0.9997-0.9999. In order to ensure the accuracy and precision of data, the standard solution (GSB04-17672004) was provided by the national nonferrous metals and electronic materials analysis and testing center for quality control. Standard recovery rates ranged from $87.53 \%$ to $102.29 \%$.

\subsection{Evaluation method}

Evaluation standards for heavy metals in water refers to the surface water environmental quality standard GB3838-2002. The Water Quality Index method (WQI), Nemero Pollution Index method (Pn), Geological Accumulation Index method (I-geo) and Potential Ecological Risk Index method (RI) were selected to evaluate the heavy metal pollution situation in the FRB.

\subsubsection{Water quality index method and Nemero index}

The water quality index is divided into "single factor pollution index method" and "comprehensive pollution index method". The former indicates the pollution level of a single heavy metal, while the latter takes into account the synergistic effects of pollutants (Duodu et al. 2016; Yan et al. 2016). The calculation formula was as 
follows (1) (2):

(1) Single factor pollution index: $\mathrm{Pi}=\frac{C_{i}}{Q_{i}}$ Where $C i$ is the heavy metal measured concentration; $Q i$ the reference value of the element.

(2) Comprehensive pollution index: $\mathrm{WQI}=\frac{1}{n} \sum_{i}^{n} P_{i}$ Where $P i$ is the single heavy metal pollution index; $n$ types of elements.

The Nemero comprehensive pollution index method can reflect current heavy metal pollution in water and the different contributions of various heavy metals. The calculation formula was as follows (3):
(3) $P_{n}=\sqrt{\frac{\max (P i)^{2}+\operatorname{ave}(P i)^{2}}{2}}$

\subsubsection{Geological accumulation index method}

Geological accumulation index method (I-geo) (Muller 1969) is widely used to evaluate heavy metal pollution in sediments. It reflects both the natural variation characteristics of heavy metal distributions, but also identifies the impact of human activities on the environment. The equation is described as below:

$$
\text { I-geo }=\log _{2}\left[C_{i} /\left(k * B_{i}\right)\right]
$$

Where: $C_{i}$ is the heavy metal measured concentration; $B_{i}$ is the geochemical background value of the heavy metal; $k$ is the diagenetic coefficient, the value is taken to be 1.5 in order to explain the possible changes in the environmental background values; I-geo is the geological accumulation index.

\subsubsection{Potential ecological risk index method}

The index method of potential ecological risk ${ }^{33}$ (Hakanson 1980) 

of heavy metals and is calculated as follows:

$$
\begin{gathered}
E_{r}^{i}=T_{r}^{i} \times\left(C^{i} / C_{n}^{i}\right) \\
\mathrm{RI}=\sum_{i}^{n} E_{r}^{i}
\end{gathered}
$$

Where $C i$ is the heavy metal measured concentration; $C_{n}^{i}$ is the reference value of the element; $T_{r}^{i}$ is the toxic reaction coefficient of each element $(\mathrm{Cu}=\mathrm{Pb}=\mathrm{Ni}=5$, 2015); $E_{r}^{i}$ is the single element potential ecological risk factor. Classification standards of WQI, I-geo, and RI are presented in Table1.

\subsection{Statistical analysis}

IBM SPSS Statistic 22.0 was used for statistical analysis. Pearson Correlation Analysis (CA) is used to analyze the correlation between the various elements.

213 Hierarchical Clustering Analysis (HCA) is used to group the sampling points according to the metal concentration of the sampling points. Variables with close distance were clustered first, followed by the variables with far distances until each

216 variable is in an appropriate class. Intergroup link method and square Euclidean 217 distance, recognized as the most stable method of systematic clustering analysis, are 218 used in this study. Principal Component Analysis (PCA) focuses on explaining the 219 total variance of each variable through dimensionality reduction (Shin and Lam 220 2001; Tetsuro et al. 2009). In this study, Principal Component Analysis (PCA) 221 explores the relationship between elements by extracting a small number of potential factors and analyzes the similarity of distribution sources of heavy metals. 


\subsection{Positive matrix factorization (PMF)}

Positive Matrix Factorization (PMF), a multivariable factor analysis method (Paatero and Tapper 1993), is used to analyze the sources of heavy metals in this study (Peng et al. 2016). As the original sample data matrix $X(x \times j)$ was decomposed into the product of factor contribution matrix $G(i \times k)$ and factor profile matrix $F(k \times$ $j)$ by the PMF model, as well as the sum of residuals matrix $E(i \times j)$. The calculation equation is as follows:

$$
\begin{gathered}
\mathrm{X}=\mathrm{G} \times \mathrm{F}+\mathrm{E} \\
\mathrm{x}_{i j}=\sum_{k=1}^{p} \mathrm{~g}_{i k} \times \mathrm{f}_{k j}+\mathrm{e}_{i j}
\end{gathered}
$$

Where, $x_{i j}$ is the concentration of sample component $j$ at the $i$ sample point $(\mathrm{mg} / \mathrm{kg}) ; g_{i k}$ is the source $k$ contribution concentration at $i$ sampling point $(\mathrm{mg} / \mathrm{kg})$; $f_{k j}$ represents the contribution of source $k$ to sample component $j ; e_{i j}$ represents the residual, and $p$ represents the number of source factors.

PMF model is iterated by the least square method, and the original matrix $X$ is split to obtain the optimal matrix $G$ and $F$, so that the objective function $Q$ approaches the degree of freedom value, namely $i \times j$. $Q$ is defined as follows:

$$
Q=\sum_{i=1}^{n} \sum_{j=1}^{m}\left({ }^{e_{i j}} / \mathrm{u}_{i j}\right)^{2}
$$

Where, $u_{i j}$ represents the uncertainty of sample component $j$, and $e_{i j}$ represents the residual.

\section{Results and discussion}

\subsection{Water quality parameters}


The physical and chemical parameters of water, such as temperature $\left({ }^{\circ} \mathrm{C}\right), \mathrm{pH}$,

dissolved oxygen (DO), redox potential (ORP), and electrical conductivity (EC) are presented in Table 2. Physical and chemical parameters are important to understand given their role in supporting aquatic life and environmental health. The temperature range (taken in winter) is from 6.55 to $15.05^{\circ} \mathrm{C}$. Sampling sites FY and GGY have lower values than other sites due to the upstream location and high altitude. The values of $\mathrm{pH}$ ranged from 7.88 to 8.49 (Table 2), within limits prescribed by GB38382002. The water quality in the Fenghe River is slightly alkaline. The average range for DO is between 5.24 and $11.25 \mathrm{mg} / 1$ (Table 2). Variability in DO may be due to aerobic and organic decomposition of aquatic organisms. Redox potential is a measurement index of water redox capacity. Higher values indicate higher oxidizability. The redox potential ranged from 138.62 to $176.77 \mathrm{mV}$. The electrical conductivity represents the content of soluble impurities in water, and higher values represent worse water quality. The lowest value of $0.07(\mathrm{~ms} / \mathrm{cm})$ for electrical conductivity is located in sampling site FY, which is in the upstream, while the highest value of $0.95(\mathrm{~ms} / \mathrm{cm})$ appears in sampling site YRF, which may be the result of discharge from surrounding enterprises and residential wastewater.

\subsection{Heavy metal concentration in water and sediment}

The concentrations of heavy metals in water are shown in Table 3. At present, there are some studies on heavy metals in water, possibly because they precipitate quickly and tend to accumulate in sediments (Simpson and Batley 2010). However, 
once secondary contamination occurs, trace concentrations may endanger aquatic organism, accumulate in the foodweb, and eventually pose a threat to human health (Salem et al. 2014). The average concentration of heavy metals in water decreases according to: $\mathrm{Sr}>\mathrm{Fe}>\mathrm{Mn}>\mathrm{Zn}>\mathrm{Cr}>\mathrm{Ti}>\mathrm{Ni}>\mathrm{Cu}>\mathrm{As}>\mathrm{Pb}>\mathrm{Cd}$. The highest concentration of $\mathrm{Sr}$ was $322.85 \mathrm{ug} / \mathrm{L}$ in sampling site $\mathrm{FHK}$ and the lowest concentration of $\mathrm{Sr}$ was $54.12 \mathrm{ug} / \mathrm{L}$ in sampling stie FY. The average concentration of Fe was observed with the value of $7.29 \mathrm{ug} / \mathrm{L}$ for sampling site FY and $269.15 \mathrm{ug} / \mathrm{L}$ for sampling site TPY. The highest concentration of Fe is slightly below Class I water quality standards and within the drinking water standard range. The concentration of Mn ranges from $0.8 \mathrm{ug} / \mathrm{L}$ to $239.8 \mathrm{ug} / \mathrm{L}$. The concentrations of $\mathrm{Mn}$ in sampling sites TPY, FHK and QDZ exceeded the three standards of surface water (GB3838-2002). The average concentration of $\mathrm{Zn}$ was between 7.34 and $19.86 \mathrm{ug} / \mathrm{L}$. $\mathrm{Zn}$ can be used as a nutrient at low concentrations, but exceeding the threshold can cause toxicity to aquatic organisms. Interestingly, the highest value of $\mathrm{Zn}$ was observed at sampling site YRF site, which might be attributed to wastewater discharge from an electronics factory. The concentrations of $\mathrm{Cr}$ were uniformly distributed, ranging from 6.13 to $7.56 \mathrm{ug} / \mathrm{L}$, which were lower than the Class I surface water standards (GB3838 2002) but higher than the WHO standard (5 ug/L) (Table 3). The highest concentration of $\mathrm{Ti}, \mathrm{Ni}$ and $\mathrm{Pb}$ were $8.54,3.95,1.51 \mathrm{ug} / \mathrm{L}$, respectively. They are all observed in sampling site TPY, probably because it is surrounded by residential areas, machinery and equipment companies. The concentration range of $\mathrm{Cu}(1.54-2.92 \mathrm{ug} / \mathrm{L})$, As (0.2$2.66 \mathrm{ug} / \mathrm{L})$, and $\mathrm{Cd}(0.03-0.1 \mathrm{ug} / \mathrm{L})$ are lower than Class I water quality standards 
(GB3838 2002). The highest concentrations of heavy metals are in the middle reaches of the river, except for $\mathrm{Cd}$. $\mathrm{Cd}$ is a highly mobile and toxic element that is easily released into the environment (Li et al. 2012). In general, concentrations of heavy metals in water are not high in the downstream, such as sampling site SLQ, due to pollution source control during recent sponge city development. In general, concentrations of heavy metals in water are lower than in sediment, possibly due to the fluidity and dilution of the water (Mohiuddin et al. 2012).

The concentration of heavy metals in sediment is shown in Table 4. The average concentration of heavy metals are between $615.25-736.40 \mathrm{mg} / \mathrm{kg}$ for $\mathrm{Mn}, 221.50-$ $409.00 \mathrm{mg} / \mathrm{kg}$ for Sr, $182.20-281.30 \mathrm{mg} / \mathrm{kg}$ for As, $74.33-125.10 \mathrm{mg} / \mathrm{kg}$ for Zn, $50.66-$ $79.01 \mathrm{mg} / \mathrm{kg}$ for $\mathrm{Cr}, 26.56-33.33 \mathrm{mg} / \mathrm{kg}$ for $\mathrm{Pb}, 18.21-48.10 \mathrm{mg} / \mathrm{kg}$ for $\mathrm{Cu}, 21.06-34.01$ $\mathrm{mg} / \mathrm{kg}$ for Ni, $0.18-0.48 \mathrm{mg} / \mathrm{kg}$ for Cd. They decreased successively according to: $\mathrm{Mn}>\mathrm{Sr}>\mathrm{As}>\mathrm{Zn}>\mathrm{Cr}>\mathrm{Pb}>\mathrm{Cu}>\mathrm{Ni}>\mathrm{Cd}$. Average concentration of these elements ( $\mathrm{Mn}, \mathrm{Sr}, \mathrm{As}, \mathrm{Zn}, \mathrm{Cr}, \mathrm{Pb}, \mathrm{Cu}, \mathrm{Cd}$ ) exceeds background values of Shaanxi soils. Ni is lower than the soil environmental background value of $28.8 \mathrm{mg} / \mathrm{kg}$ in Shannxi province, but higher than the average value $25.6 \mathrm{mg} / \mathrm{kg}$ for the Wei River (Table 4). The excessive multiples of heavy metal concentration for the maximum point position concentration of $\mathrm{Mn}, \mathrm{Sr}, \mathrm{As}, \mathrm{Zn}, \mathrm{Cr}, \mathrm{Pb}, \mathrm{Cu}, \mathrm{Cd}$ are $0.32,1.46,24.34,0.80,0.26,0.56$, $1.25,4.14$. In addition to the proportion exceeding the standard value of heavy metal concentration for sampling points were $40 \%$ for $\mathrm{Cr}$, $\mathrm{Ni}$ and $60 \%$ for $\mathrm{Cu}$, as well as $100 \%$ for $\mathrm{Mn}, \mathrm{Sr}, \mathrm{As}, \mathrm{Zn}, \mathrm{Pb}, \mathrm{Cd} . \mathrm{Pb}$ and $\mathrm{As}$ are above average shale values (Table 4). The maximum values of $\mathrm{Mn}, \mathrm{As}, \mathrm{Zn}, \mathrm{Cr}, \mathrm{Pb}, \mathrm{Cu}$ and $\mathrm{Ni}$ were found at the sampling 
site FHK, Ti and Cd in sampling site SLQ, and Sr in sampling site TPY. The FHK sampling site is close to farmland, residential areas and surrounding materials technology companies, which reflect complex sources of heavy metals. There are automobile, printing and titanium companies around the SLQ sampling site, which may also explain high concentrations of $\mathrm{Ti}$ and $\mathrm{Cd}$. At the TPY sampling point, the mechanical, petroleum, and metallurgical industries may be sources of $\mathrm{Sr}$ contamination.

\subsection{Evaluation of heavy metal pollution in water and sediment}

Water Quality Index (WQI) evaluation for the FRB is presented in Fig. 2 a. The WQI values of each sampling point from upstream to downstream are $0.15,0.19$, $0.56,1.39,0.40,0.39,0.74$, and 0.43 respectively. Among them, WQI value of sampling site YRF is within the range of $1 \sim 2$, which belongs to low pollution. None of the other sampling sites were contaminated with heavy metals. According to the Pn of each sampling point (Fig. 2 b), YRF and YJQ sampling points are highly polluted. The pollution levels of TPY and YJQ sampling points are equivalent with moderate pollution indicators. The Pn of FHK and QDZ sampling points are 0.99 and 0.89 , indicating low pollution levels (between 0.7 and 1). Nemero index evaluation is basically consistent with an overall pollution trend of: YRF $>$ YJQ $>$ TPY $>$ SLQ $>$ FHK $>$ QDZ $>$ GGY $>$ FY. The overall pollution trend of the FRB is that the middle reaches are the most seriously polluted, followed by the downstream and the upstream. However, the pollution degree obtained by different 
evaluation methods is somewhat different. For example, the WQI of YRF site shows low pollution while Pn shows high pollution. The WQI of YJQ, TPY and SLQ sites are no-pollution while Pn shows high-pollution, medium-pollution, and mediumpollution respectively. The WQI of FHK and QDZ sites are no-pollution while Pn shows low pollution. WQI reflects the average pollution level of multiple heavy metals. Pn considers the average pollution level and the influence of high heavy metal concentration.

The calculated Geological Accumulation Index (I-geo) and Potential Ecological Risk Index (RI) of heavy metals in sediment are summarized in Fig3. In Fig3 a, the Igeo ranged from -0.70 to 3.89 . Among the studied metals, the I-geo values decreased as: $\mathrm{As}>\mathrm{Cd}>\mathrm{Sr}>\mathrm{Pb}>\mathrm{Zn}>\mathrm{Cu}>\mathrm{Mn}>\mathrm{Cr}>\mathrm{Ni}$. Among these sample sites, the range of I-geo values for As was 3.45-4.08, indicating high pollution to very high pollution in this sediment. I-geo values for $\mathrm{Cd}$ and $\mathrm{Sr}$ were $0.34-1.78$ and $-0.17-0.72$ respectively, which indicating no pollution to moderate pollution. I-geo values of other element indicated no contamination in the basin. The Potential Ecological Risk Index (RI) was also calculated and used to assess the ecological risk of heavy metals in the sediment of the FRB (Fig3 b). In these sampling points, the trend showed gradually decreasing pollution as: $\mathrm{SLQ}>\mathrm{FHK}>\mathrm{YJQ}>\mathrm{YRF}>\mathrm{TPY}$. The Single factor ecological risk $\operatorname{index}\left(E_{r}^{i}\right)$ is divided into 5 levels in total: $E_{r}^{i}<40$, low potential risk; $40<E_{r}^{i} \leq 80$, moderate potential risk; $80<E_{r}^{i} \leq 160$, considerable potential risk; $160<E_{r}^{i} \leq 320$, high potential risk; $E_{r}^{i}>320$, very high potential risk ${ }^{62}$ (Maanan et al. 2015). According to the calculation results, the single factor ecological risk index $\left(E_{r}^{i}\right)$ of $\mathrm{Cd}$ ranges 
353

354

from 56.81 to 154.15 , which indicats that $\mathrm{Cd}$ has high ecological risks in FHK and SLQ sample sites and considerable ecological risks in other sites. The $E_{r}^{i}$ of As ranges from 164.14 to 253.42 , indicating high ecological risk. From each sampling point, the RI values are in the range from 313.24 to 375.59 . This result demonstrates that the study area presents moderate potential risk. According to the calculation results of WQI and RI, the pollution degrees of water and sediment are not always consistent with the ecological risk, which may be related to the complex influencing factors of heavy metal pollution. Therefore, the combination of pollution degree and ecological risk is useful for comprehensive analysis of heavy metal pollution risk.

\subsection{Multivariate statistical analysis}

The Pearson Correlation Analysis of heavy metals reflects the relationship between heavy metals, so as to determine the source and migration of heavy metals (Yi et al. 2012). If the correlation between elements is low, it indicates that heavy metals are affected by complex factors (Kükrer et al. 2014). Pearson Correlation Analysis (CA) between heavy metals in water and sediment is elucidated in the Pearson Correlation Matrix (Table 5). However, significantly positive correlations $(p<0.01)$ and positive correlations of $p<0.05$ were found among different elements. Heavy metals with high correlation have similar sources. In water, Fe was found to be significantly positively correlated with $\mathrm{Mn}, \mathrm{Cr}, \mathrm{Ni}, \mathrm{Ti}$, but positively correlated with $\mathrm{Sr}$. Ti also shows significant positive correlatation with $\mathrm{Pb}$. Mn is positively correlated with $\mathrm{Pb}$. $\mathrm{Cr}-\mathrm{Ni}$ (0.753), $\mathrm{Cr}-\mathrm{Cu}(0.814), \mathrm{Cr}-\mathrm{Sr}(0.817)$, Ni-Sr (0.758), Ni-Pb (0.772), 
$\mathrm{Cu}-\mathrm{Sr}$ (0.801), As-Sr (0.802) were also positively correlated (Table 5). In sediment, there was significant positive correlation between $\mathrm{Mn}$ and $\mathrm{Pb}, \mathrm{Cr}$ and $\mathrm{Ni}, \mathrm{Cu}$ and $\mathrm{Zn}$. Moreover, $\mathrm{Ni}$ and $\mathrm{Sr}$ exhibited a significant negative correlation of -0.979 . And the $\mathrm{Cr}-\mathrm{Cu}$ (0.913), $\mathrm{Cr}-\mathrm{Zn}$ (0.924), Ni-Cu (0.941) and Ni-Zn (0.946) showed positive correlations in sediment. However, $\mathrm{Cr}$ and $\mathrm{Sr}$ exhibited negative correlations of -0.940 (Table 5).

The dendrogram of Hierarchical Cluster Analysis (HCA) are shown in Figs. 4a and $\mathbf{4 b}$ for water and sediment respectively. In water, all sample sites can be divided into three main types. Sample sites FY, GGY are grouped into Cluster 1. Cluster 2 includes YJQ, SLQ, YRF, and QDZ. The other sites FHK, TPY fall into Cluster 3. Results show that monitoring points assigned to the same group which have similar pollution sources and backgrounds. Group 1 is mainly from the upstream and is largely uncontaminated. Group 2 is mainly distributed in the middle and lower reaches, where the YRF sampling points may reflect heavy metals from sewage outlets. Group 3 is clustered together, possibly because the rivers in the middle and upper reaches were distributed around residents, farmland and orchards. It indicates that there is a significant difference between the upstream and the middle and downstream, so that the source of heavy metals can be preliminarily determined. In sediment, the YRF, YJQ, and TPY samples in the middle stream are classified into Cluster 1, the SLQ and FHK sample sites were grouped in Cluster 2 and 3 respectively. Heavy metal pollution in the downstream area is serious, followed by the FHK sample sites, which is consistent with the result of the Potential Risk Evaluation Index (RI). 

components analysis (PCA) in water and sediment are presented in Table 6. The extracted eigenvalues of the three principal components (PCs) or factors are all greater than 0.25 . PCA reduced the dimensionality of the initial dataset to 3 components in water and 2 components in sediment, which explained $87.97 \%$ and $89.90 \%$ of the data variance, respectively. Therefore, the three factors and two factors play a very important role in explaining the heavy metal pollution in the study area. In water $\mathrm{PC} 1, \mathrm{Mn}, \mathrm{Fe}, \mathrm{Ni}, \mathrm{Pb}$, and Ti have the highest loadings and accounts for $42.85 \%$ of the Earth's crust. $\mathrm{Ni}$ and $\mathrm{Pb}$ may be related to the electronics industry and urban transportation. $\mathrm{PC} 2, \mathrm{Cr}, \mathrm{Cu}, \mathrm{As}, \mathrm{Sr}$, and $\mathrm{Cd}$ have high loadings and account for $33.175 \%$ of the variance. As is the single dominant metal for PC3, Zn may come from pigment, plastics and some commercial activities. In sediment samples, $\mathrm{PC} 1, \mathrm{Cr}, \mathrm{Ni}$, model. $\mathrm{Cu}, \mathrm{Zn}$, and $\mathrm{Sr}$ have the highest loadings and account for $55.76 \%$ of the total variance, while, $\mathrm{Cd}$, As, Ti, Mn, and Pb represent PC2 with loadings that account for $34.14 \%$ of the variance. More detailed classification and factor analysis were explored by PMF

PMF model is run in order to better determine the source of the heavy metals in the FRB in Shannxi province. The source apportionment results and factor

\subsection{Positive matrix factorization}

contribution percentages of heavy metals in water and sediment are shown in Figs. 5a 
and $\mathbf{5 b}$. From the diagram, we can see the difference between the concentration of the elements and the percentage contribution. For example, in water for Factor 1, Sr has a high concentration but a low contribution rate of $17.5 \%$. However, in sediment for Factor $1, \mathrm{Cd}$ has a low concentration but a high contribution rate of $76.2 \%$. It does not matter whether a particular metal exhibits a high concentration in a particular factor; what matters is whether the metal accounts for a large proportion in that factor. Although it cannot be denied that there is a direct relationship between concentration and percentage, it means that the percentage of heavy metals under certain factors is more significant than the concentration. As a result, heavy metal concentrations and percentages are shown in the chart through PMF models, which play a significant role in explaining and analyzing the distribution of pollution sources.

In water, Factor 1, which constitutes a moderate $36.8 \%$ of the contribution (Fig. 6 a), has higher loadings of $\mathrm{Mn}(60.9 \%)$, Fe (46.8\%) and $\mathrm{Ti}(50.9 \%)$. The background values of these elements are high, and since they are the dominant elements in the Earth's crust (Pehlivan 2010), the may be partly derived from natural causes (recent loess of parent material) (Yang et al. 2014) and partly from companies such as the chemical machinery. This conclusion is also consistent with the results of PCA and HCA, and there is a strong correlation between these elements. Factor 2, which accounted for a lower portion (11.7\%) of the contribution (Fig. 6 a), mainly includes As (72.6\%), Sr (47.3\%) and $\mathrm{Ni}(33.0 \%)$. Ni and As may be associated with some of the electronics companies that are regional distributed. $\mathrm{Sr}$ is an alkaline earth metal, usually in the form of $\mathrm{SrSO}_{4}$ and $\mathrm{SrSO}_{3}$ in the Earth's crust ${ }^{67}$ (Jie et al. 2014). A large 
number of digital cathode ray tubes are derived from $\mathrm{SR}^{68}$ (Hibbins 2000), so the source of Sr may be from YJQ sampling point. Factor 3, which explains only the contribution of $9.4 \%$ (Fig. 6 a), is correlated quite well with $\mathrm{Cd}(99.8 \%$ ), and followed by $\mathrm{Cr}(37.9 \%)$ and $\mathrm{Cu}(31.3 \%)$. Some light industries, such as alloy, components and lubricants, can result in significant copper and chromium emissions (Mirbagheri and Hosseini 2005; Yeung et al. 2003). At the same time, Cd is closely related to fertilizers, pesticides and disinfectants (Mansour et al. 2009). The Fenghe River runs through the city center and suburbs of Xi'an city, and some enterprises, residents, farmland and orchards (vineyards and strawberry fields) are distributed around the sampling site, which may be the main sources of $\mathrm{Cu}, \mathrm{Cr}$ and $\mathrm{Cd}$ pollution. Factor 4, which accounted for a very large percentage $42.0 \%$ of the contribution (Fig. 6 a), contained $\mathrm{Zn}(49.1 \%)$ and $\mathrm{Pb}(33.2 \%)$. The source of $\mathrm{Zn}$ and $\mathrm{Pb}$ are mainly from electronics industry and urban transportation. Leaded gasoline can cause water pollution of $\mathrm{Pb}$ through atmospheric subsidence (Miguel et al. 1997).

$$
\text { In sediment, the proportion of the last three factors is relatively uniform. Factor 1, }
$$
which makes up the minimum proportion $8.0 \%$ of the contribution (Fig. 6 b), is composed essentially of $\mathrm{Cd}(72.6 \%)$. As in the case of Factor 3 in water by PMF analysis, $\mathrm{Cd}$ occupies the largest contribution rate. It is obvious that $\mathrm{Cd}$ is related to agronomic activity (fertilizer, pesticide, insecticide and disinfectant) ${ }^{73,74}$ (Wang et al. 2015; Jian-Long et al. 2014), which is mainly distributed in the middle and lower reaches of the study area. Factor 2, which presented 29.2\% of the contribution (Fig. 6 b), is constituted by $\mathrm{Cu}(49.5 \%), \mathrm{Zn}(34.7 \%)$ and $\mathrm{Ni}(33.0 \%)$. Factor 3, which 
accounted for $23.9 \%$ of the contribution (Fig. 6 b), is made up of $\mathrm{Cu}(31.0 \%)$ and $\mathrm{Zn}$ $(22.2 \%)$. These metals are mainly related to tourism in the upstream of the study area, the construction of towns in the middle reaches and the industry in the downstream. Each element of this factor accounts for a small proportion, indicating that it should be given less attention in future pollution control plans. Factor 4 accounted for $38.9 \%$ of the contribution (Fig. 6 b), and most elements are included in this factor. For example, it includes $\mathrm{Sr}(96.8 \%)$, As (63.8\%), $\mathrm{Pb}(56.5 \%), \mathrm{Mn}(55.6 \%)$, Ti (47.8\%) and $\mathrm{Cr}(31.9 \%)$. These metals are primarily derived from human activities and are concentrated in the automobile, printing, metallurgy, materials, and petroleum machinery industries (Yang et al. 2013; Chowdhury and Maiti 2016; Loska and Wiechuła 2003).

\section{Conclusion}

We present a preliminary assessment and source analysis of heavy metal elements in water and surface sediment in the FRB. The concentration, distribution, enrichment characteristics, potential risks and sources of heavy metals were taken into account comprehensively. The results show that most metals do not meet national water quality standards, except for Mn which exceeds the Class III water quality standard and $\mathrm{Cr}$ which is higher than the drinking water standard. However, all the elements in the sediments except $\mathrm{Ni}$ were higher than the soil environmental background value in Shaanxi province. The results of WQI and Pn show that the most serious pollution is in sampling site YRF, possibly due to direct emissions from sewage outlets. I-geo indicates that As is highly concentrated in the sediments. $E_{r}^{i}$ and 
483

484

RI show that $\mathrm{Cd}$ in sediment has a high ecological risk at sampling sites FHK and SLQ and a moderate ecological risk at other sites. As in sediment has high ecological risk for all sampling stations. Results for CA, HCA, and PCA confirm the results of water and sediment analysis, although there are a few differences due to the government's control for downstream sites and some special pollution sources such as factories, businesses, residents, town building and agricultural activity (fields and orchards) in the middle reaches. The factors or sources of heavy metals in water and sediment are revealed in detail through PMF models. In the water, the average contribution rate of these four source factors for heavy metals is $36.8 \%, 11.7 \%, 9.4 \%$ and $42.0 \%$, while the average proportion of these four factors for heavy metals in sediment is $8.0 \%, 29.2 \%, 23.9 \%$ and $38.9 \%$ respectively. Most of the river basin is influenced by human activities, mainly town construction and transportation, some light industry, machinery and electronics material companies, tourism, and agronomy. Future control and prevention should focus on these aspects in order to provide better ecological and environmental benefits for the FRB.

\section{Declarations}

\subsection{Ethics approval and consent to participate}

All procedures performed in studies involving human participants were in accordance with the ethical standards of the institutional and/or national research committee and with the 1964 Helsinki Declaration and its later amendments or comparable ethical standards. The study was approved by National Key R\&D 


\subsection{Consent for publication}

Not applicable for that section.

\subsection{Availability of data and materials}

508

509

510

511

512

513

514

515

516

517

518

519

520

521

522

The data that support the findings of this study are available from Eight water quality monitoring stations in the Fenghe River Basin but restrictions apply to the availability of these data, which were used under license for the current study, and so are not publicly available. Data are however available from the authors upon reasonable request and with permission of Eight water quality monitoring stations in the Fenghe River Basin.

\subsection{Competing interests}

The authors declare that they have no known competing financial interests or personal relationships that could have appeared to influence the work reported in this paper.

\subsection{Funding}

Financial support was provided by National Key R\&D Program of China (2018YFGH000187), the Fundamental Research Funds for the Central Universities, CHD (300102299302), International Collaborative Research of Disaster Prevention Research Institute of Kyoto University(2019W-02), One Hundred Talent Plan of 
523 Shaanxi Province, Excellent projects for science and technology activities of overseas 524 staff in Shaanxi Province (2018038), and Special funds of education and teaching 525 reform for the Central Universities of China (310629172112). The funders had no role 526 in study design, data collection and analysis, decision to publish, or preparation of the 527 manuscript.

\subsection{Authors' contributions}

All authors contributed to the study conception and design. Material preparation, 530 data collection and analysis were performed by Aidi Huo, Daniel Nover and Shuxin 531 Kang. Table and Figure editing are performed by Meimei Zhou, Jiqiang Lyu and 532 Pingping Luo. The first draft of the manuscript was written by Chengyi $\mathrm{Xu}$ and all 533 authors commented on previous versions of the manuscript. All authors read and 534 approved the final manuscript. 
Angulo E. 1996. The Tomlinson Pollution Load Index applied to heavy metal, 'Mussel-Watch' data: a useful index to assess coastal pollution. Science of the Total Environment 187(1):19-56. Finland by positive matrix factorization. Atmospheric Environment 29(14):1705-1718. drainage basin of smelting activities. Water Research 29(7):1729-1736. quality assessment of Hun River. Ecology \& Environmental Sciences.

Chowdhury A, Maiti SK. 2016. Identifying the source and accessing the spatial variations, contamination status, conservation threats of heavy metal pollution in the river waters of Sunderban biosphere reserve, India. Journal of Coastal Conservation 20(3):257-269. Systems 107(1):24-30. heavy metal in Brisbane River sediment 弥. Environmental Pollution 219:1077-1091. sediments from the two coastal inlets (Golden Horn Estuary and İzmit Bay) of the northeastern Sea of Marmara. Chemical Geology 91(3):269 - 285. 
Facchinelli A, Sacchi E, Mallen L. 2001. Multivariate statistical and GIS-based approach to identify heavy metal sources in soils. Environmental Pollution 114(3):313-324.

Giri S, Singh AK. 2014. Risk assessment, statistical source identification and seasonal fluctuation of dissolved metals in the Subarnarekha River, India. Journal of Hazardous Materials 265(2):305-314.

Grabowski LA, Houpis JL, Woods WI, Johnson KA. 2001. Seasonal bioavailability of sedimentassociated heavy metals along the Mississippi river floodplain. Chemosphere 45(4):643-651.

Guo Y, Yang S. 2016. Heavy metal enrichments in the Changjiang (Yangtze River) catchment and on the inner shelf of the East China Sea over the last 150 years. Science of the Total Environment 543(Pt A):105-115.

Hakanson L. 1980. An ecological risk index for aquatic pollution control.a sedimentological approach.

Water Research 14(8):975-1001.

Hibbins SG. 2000. Stront Hakanson ium and Strontium Compounds.

Huaien LI, Ding J, Wang L. 2016. Research on interannual variation characteristics of non-point source pollution on control section of Fenghe River. Journal of Water Resources \& Water Engineering.

Islam MS, Ahmed MK, Habibullah-Al-Mamun M, Hoque MF. 2015. Preliminary assessment of heavy metal contamination in surface sediments from a river in Bangladesh. Environmental Earth Sciences 73(4):1837-1848.

Jaeckels JM, Bae MS, Schauer JJ. 2007. Positive matrix factorization (PMF) analysis of molecular marker measurements to quantify the sources of organic aerosols. Environmental Science \& Technology 41(16):5763-5769.

Jian-Long X, Yu-You Z, Li-Ping Y, Jia-Chun S, Ling-Zao Z, Lao-Sheng W. 2014. Positive matrix factorization as source apportionment of soil lead and cadmium around a battery plant (Changxing 

sediments of northern littoral zone of Lake Çıldır, Ardahan, Turkey. Environmental Monitoring \& Assessment 186(6):3847-3857. heavy metals in the water of Chaohu Lake, Anhui, China. Environmental Monitoring \& Assessment 184(5):2763.

Li M, Zang S, Xiao H, Wu C. 2014. Speciation and distribution characteristics of heavy metals and pollution assessments in the sediments of Nashina Lake, Heilongjiang, China. Ecotoxicology 23(4):681-8.

Li S, Zhang Q. 2010. Risk assessment and seasonal variations of dissolved trace elements and heavy metals in the Upper Han River, China. Journal of Hazardous Materials 181(1):1051-1058. 
602

603

604

605

606

607

608

609

610

611

612

613

614

615

616

617

618

619

620

621

622

623

Lin JG, Chen SY. 1998. The relationship between adsorption of heavy metal and organic matter in river sediments. Environment International 24(3):345-352.

Lin Q, Liu E, Zhang E, Li K, Shen J. 2016. Spatial distribution, contamination and ecological risk assessment of heavy metals in surface sediments of Erhai Lake, a large eutrophic plateau lake in southwest China. Catena 145:193-203.

Loska K, Wiechuła D. 2003. Application of principal component analysis for the estimation of source of heavy metal contamination in surface sediments from the Rybnik Reservoir. Chemosphere 51(8):723-733.

Macdonald DD, Ingersoll CG, Berger TA. 2000. Development and evaluation of consensus-based sediment quality guidelines for freshwater ecosystems. Arch Environ Contam Toxicol 39(1):20-31.

Mansour SA, Belal MH, Abou-Arab AAK, Gad MF. 2009. Monitoring of pesticides and heavy metals in cucumber fruits produced from different farming systems. Chemosphere 75(5):601-609.

Miguel DE, J. F, CHACON, BERG, LARSSEN. 1997. Origin and patterns of distribution of trace elements in street dust: Unleaded petrol and urban lead. Atmospheric Environment 31(31):2733-2740.

Mirbagheri SA, Hosseini SN. 2005. Pilot plant investigation on petrochemical wastewater treatmentfor the removal of copper and chromium with the objective of reuse. Desalination 171(1):85-93.

Mohamed M. 2007. Heavy metal concentrations in marine molluscs from the Moroccan coastal region. Environmental Pollution 153(1):176-183.

Mohiuddin KM, Otomo K, Ogawa Y, Shikazono N. 2012. Seasonal and spatial distribution of trace elements in the water and sediments of the Tsurumi River in Japan. Environmental Monitoring \& Assessment 184(1):265-279.

Mu D, Luo P, Lyu J, Zhou M, Huo A, Duan W, Nover D, He B, Zhao X. 2020. Impact of temporal 
rainfall patterns on flash floods in Hue City, Vietnam, Journal of Flood Risk Management. e12668.

Muller G. 1969. Index of geoaccumulation in sediments of the Rhine River. Geojournal 2(108):108118.

Nan Yan, Wenbin Liu, Huiting Xie, Lirong Gao, Ying Han, Mengjing Wang, HaiFeng Li. 2016. Distribution and assessment of heavy metals in the surfaces ediment of Yellow River, China. Journal of Environmental Sciences 39(1):45-51.

NAZEER, Summiya, Hashmi MZ, Malik RN. 2014. Heavy metals distribution, risk assessment and water quality characterization by water quality index of the River Soan, Pakistan. Ecological Indicators 43(43):262-270.

Ndimele PE. 2012. The effects of water hyacinth (Eichhornia crassipes [Mart.] Solms) infestation on the physico-chemistry, nutrient and heavy metal content of Badagry Creek and Ologe Lagoon, Lagos, Nigeria. Journal of Environmental Science \& Technology 5(2):128-136.

Ogendi GM, Brumbaugh WG, Hannigan RE, Farris JL. 2010. Effects of acid-volatile sulfide on metal bioavailability and toxicity to midge (Chironomus tentans) larvae in black shale sediments. Environmental Toxicology \& Chemistry 26(2):325-334.

Paatero P, Tapper U. 1993. Analysis of different modes of factor analysis as least squares fit problems. Chemometrics \& Intelligent Laboratory Systems 18(2):183-194.

Pandey SK, Bhattacharya T. 2016. Mobility, Ecological risk and change in surface morphology during sequential chemical extraction of heavy metals in fly ash: A case study. Environmental Technology \& Innovation.

Parparov A, Hambright KD, Berman T. 1992. Water Quality Assessment.

Pekey H, Karakaş D, Bakoglu M. 2004. Source apportionment of trace metals in surface waters of a 
polluted stream using multivariate statistical analyses. Mar Pollut Bull. Marine Pollution Bulletin 49(9):809-818.

Peng X, Shi GL, Liu GR, Xu J, Tian YZ, Zhang YF, Feng YC, Russell AG. 2016. Source apportionment and heavy metal health risk (HMHR) quantification from sources in a southern city in China, using an ME2-HMHR model. Environmental Pollution 221:335.

Pornsawai P, Rodenburg LA, Cavallo GJ. 2013. Source apportionment of polychlorinated biphenyls in the sediments of the Delaware River. Environmental Science \& Technology 47(9):4277-4283.

Salem ZB, Capelli N, Laffray X, Elise G, Ayadi H, Aleya L. 2014. Seasonal variation of heavy metals in water, sediment and roach tissues in a landfill draining system pond (Etueffont, France). Ecological Engineering 69(4):25-37.

Saraga DE, Maggos TE, Sfetsos A, Tolis EI, Andronopoulos S, Bartzis JG, Vasilakos C. 2010. PAHs sources contribution to the air quality of an office environment: experimental results and receptor model (PMF) application. Air Quality Atmosphere \& Health 3(4):225-234.

Shin PKS, Lam WKC. 2001. Development of a Marine Sediment Pollution Index. Environmental Pollution 113(3):281-291.

Sijin L, Yeyao W, Yanguo T, Xuan Y. 2015. Heavy metal pollution and ecological risk assessment of the paddy soils near a zinc-lead mining area in Hunan. Environmental Monitoring \& Assessment 187(10):627.

Simpson SL, Batley GE. 2010. Predicting Metal Toxicity in Sediments: A Critique of Current Approaches. Integr Environ Assess Manag 3(1):18-31.

Simpson SL, Spadaro DA. 2016. Bioavailability and Chronic Toxicity of Metal Sulfide Minerals to Benthic Marine Invertebrates: Implications for Deep Sea Exploration, Mining and Tailings Disposal. 
Environmental Science \& Technology 50(7):4061-4070.

Sun Z, Mou X, Sun W. 2016. Decomposition and heavy metal variations of the typical halophyte litters in coastal marshes of the Yellow River estuary, China. Chemosphere 147:163-172.

Sunjog K, Gacic Z, Kolarevic S, Visnjicjeftic Z, Jaric I, Knezevicvukcevic J, Vukovicgacic B, Lenhardt M. 2012. Heavy metal accumulation and the genotoxicity in barbel (Barbus barbus) as indicators of the danube river pollution. The Scientific World Journal,2012,(2012-4-26) 2012(4):351074.

Tetsuro K, Takuma F, Huynh Trung H, Shuzo T. 2009. Assessment of heavy metal pollution in river water of Hanoi, Vietnam using multivariate analyses. Bulletin of Environmental Contamination \& Toxicology 83(4):575-82.

Tianxiang NI, Yang Q, Wang J, Zhao H, Jin H, Qiao L. 2018. A new improvement of Nemero index method and its application. Hydrogeology \& Engineering Geology.

Turekian KK, Wedepohl KK. 1961. Distribution of the elements in some major units of the earth crust. Geological Society of America Bulletin 72(2):175.

USEPA. 2013. Surface Water Sampling.United States Environmental Protection Agency, Washington, DC, USA..

USEPA. 2014. Sediment Sampling. United States Environmental Protection Agency, Washington, DC, USA..

Villanueva MC, Ibarra AA. 2016. Assessing the ecological stress in a Garonne River stretch, southwest France. Ecological Indicators 67:466-473.

Wang GZ, Tang DS. 2012. Post-Evaluation of the Ecological and Environmental Impact of Water Diversion Project in the Low Reaches of Heihe River. Advanced Materials Research 518-523:1188- 
1191.

691

692

693

694

695

696

697

698

699

700

701

702

703

704

705

706

707

708

709

710

711

Wang Y, Yang L, Kong L, Liu E, Wang L, Zhu J. 2015. Spatial distribution, ecological risk assessment and source identification for heavy metals in surface sediments from Dongping Lake, Shandong, East China. Catena 125(2):200-205.

Wijnhoven S, Thonon I, Velde GVD, Leuven R, Zorn M, Eijsackers H, Smits T. 2006. The Impact of Bioturbation by Small Mammals on Heavy Metal Redistribution in an Embanked Floodplain of the River Rhine. Water Air \& Soil Pollution 177(1-4):183-210.

Yan N, Liu WB, Xie HT, Li HF. 2016. Distribution and assessment of heavy metals in the surface sediment of Yellow River, China. Journal of Environmental Sciences 39:45-51.

Yang JS, Hu XJ, Li XX, Li HY, Wang Y. 2013. Application of Principal Component Analysis (PCA) for the Estimation of Source of Heavy Metal Contamination in Sediments of Xihe River, Shenyang City. Advanced Materials Research 610-613(4):948-951.

Yang Y, Zhou ZC, Zhang FP, Wang HH, Wang RD. 2014. Spatial Distribution and Sources of Heavy Metals in Soil Samples Collected from the Riparian Area of the Fenghe River. Arid Zone Research.

Yeung ZLL, Kwok RCW, Yu KN. 2003. Determination of multi-element profiles of street dust using energy dispersive X-ray fluorescence (EDXRF). Applied Radiation \& Isotopes 58(3):339-346.

Yi W, Hu J, Xiong K, Huang X, Duan S. 2012. Distribution of Heavy Metals in Core Sediments from Baihua Lake. Procedia Environmental Sciences 16(4):51-58.

Yuan B, Min S, Gouw DE, Joost, PARRISH, David D, Sihua LU, Ming W, Zeng L, Qian Z. 2012. Volatile organic compounds (VOCs) in urban air: How chemistry affects the interpretation of positive matrix factorization (PMF) analysis. Journal of Geophysical Research Atmospheres 117(D24):24302.

Zahra A, Hashmi MZ, Malik RN, Ahmed Z. 2014. Enrichment and geo-accumulation of heavy metals 

99(1-2):320-327. 187(2):33.

and risk assessment of sediments of the Kurang Nallah-Feeding tributary of the Rawal Lake Reservoir, Pakistan. Science of the Total Environment 470-471(2):925-933.

Zhang FP, Zhao S, Zhou ZC, Wei YF. 2014. Relationship Between Changes of Land Use Pattern and Water Quality in Fenghe River Basin. Bulletin of Soil \& Water Conservation.

Zhang K, Shu L. 2010. Progress in Technology Study of Heavy Metal Pollution Control in Water Body. Journal of Environmental Management College of China.

Zhang M, Wang S, Fu B, Gao G, Shen Q. 2018. Ecological effects and potential risks of the water diversion project in the Heihe River Basin. Science of the Total Environment 619-620:794-803.

Zhang Z, Abuduwaili J, Jiang F. 2015. Heavy metal contamination, sources, and pollution assessment of surface water in the Tianshan Mountains of China. Environmental Monitoring \& Assessment

Zhang Z, Li J, Mamat Z, Ye QF. 2016. Sources identification and pollution evaluation of heavy metals in the surface sediments of Bortala River, Northwest China. Ecotoxicol Environ Saf 126:94-101.

Zhuang W, Gao X. 2015. Distributions, sources and ecological risk assessment of arsenic and mercury in the surface sediments of the southwestern coastal Laizhou Bay, Bohai Sea. Marine Pollution Bulletin 
731 Table 1 Classifications of heavy metal degree of WQI, Pn,I-geo and RI.

732 Table 2 Water quality parameters of Fenghe river basin, Shannxi Province

733 Table 3 Heavy metal average concentration (ug/L) in water sample of Fenghe river

734 basin and the reference value in water $(\mathrm{ug} / \mathrm{L})$.

735 Table 4 Heavy metal concentration $(\mathrm{mg} / \mathrm{kg})$ in sediment sample of Fenghe river basin

736 and the reference background value in water $(\mathrm{mg} / \mathrm{kg})$.

737 Table 5 Pearson Correlation matrix between heavy metal concentrations in water and 738 sediment

739 Table 6 Total interpretation variance and rotation component matrix of the principal 740 components/factors of the Fenghe river in water and sediment samples 
Table 1 Classifications of heavy metal degree of WQI, Pn,I-geo and RI.

\begin{tabular}{|c|c|c|c|c|c|c|c|c|}
\hline & & WQI & & $\mathbf{P n}$ & & I-geo & & RI $^{143}$ \\
\hline classes & Scope & $\begin{array}{c}\text { Contamination } \\
\text { degree }\end{array}$ & Scope & $\begin{array}{l}\text { Contamina } \\
\text { tion degree }\end{array}$ & Scope & $\begin{array}{c}\text { Contamination } \\
\text { degree }\end{array}$ & Scope & $\begin{array}{c}\text { Ecological } \\
\text { risk }\end{array}$ \\
\hline 0 & $<1$ & Unpolluted & $\leq 0.7$ & Unpolluted & 0 & Unpolluted & $<110$ & low risk \\
\hline 1 & $1 \sim 2$ & Slightly polluted & $0.7 \sim 1$ & $\begin{array}{l}\text { Slightly } \\
\text { polluted }\end{array}$ & $0 \sim 1$ & $\begin{array}{l}\text { Unpolluted to } \\
\text { moderately }\end{array}$ & $\begin{array}{c}110 \sim 2 \\
00\end{array}$ & Moderate risk \\
\hline 2 & $2 \sim 3$ & $\begin{array}{c}\text { Moderately } \\
\text { polluted }\end{array}$ & $1 \sim 2$ & $\begin{array}{c}\text { Moderately } \\
\text { polluted }\end{array}$ & $1 \sim 2$ & $\begin{array}{c}\text { Moderately } \\
\text { polluted }\end{array}$ & $\begin{array}{c}200 \sim 4 \\
00\end{array}$ & $\begin{array}{l}\text { Moderately } \\
\text { risk }\end{array}$ \\
\hline 3 & $\geq 3$ & Heavily polluted & $\geq 2$ & $\begin{array}{l}\text { Heavily } \\
\text { polluted }\end{array}$ & $2 \sim 3$ & $\begin{array}{l}\text { Moderately to } \\
\text { highly polluted }\end{array}$ & $\geq 400$ & $\begin{array}{c}\text { Very high } \\
\text { risk }\end{array}$ \\
\hline 4 & & & & & $3 \sim 4$ & Highly polluted & & \\
\hline 5 & & & & & $4 \sim 5$ & $\begin{array}{l}\text { Highly to very } \\
\text { highly polluted }\end{array}$ & & \\
\hline 6 & & & & & $>5$ & $\begin{array}{c}\text { Very highly } \\
\text { polluted }\end{array}$ & & \\
\hline
\end{tabular}


746

\begin{tabular}{|c|c|c|c|c|c|}
\hline Sites & Temperature $\left({ }^{\circ} \mathrm{C}\right)$ & $\mathbf{P h}$ & $\begin{array}{c}\text { Dissolved } \\
\text { oxygen (DO } \\
\text { mg/l) }\end{array}$ & $\begin{array}{c}\text { Redox } \\
\text { potential(ORP } \\
\text { mV) }\end{array}$ & $\begin{array}{c}\text { Electrical } \\
\text { conductivity } \\
(\mathrm{ms} / \mathrm{cm})\end{array}$ \\
\hline$\overline{F Y}$ & 6.55 & 8.29 & 10.88 & 149.85 & 0.07 \\
\hline GGY & 9.98 & 8.49 & 11.25 & 138.62 & 0.14 \\
\hline $\mathrm{TPY}$ & 13.20 & 7.82 & 5.24 & 144.25 & 0.46 \\
\hline YRF & 15.05 & 7.88 & 6.22 & 151.43 & 0.95 \\
\hline FHK & 13.62 & 7.94 & 8.40 & 146.37 & 0.62 \\
\hline QDZ & 12.60 & 8.06 & 9.80 & 145.92 & 0.67 \\
\hline YJQ & 11.85 & 8.40 & 9.30 & 146.72 & 0.52 \\
\hline SLQ & 11.30 & 8.46 & 9.89 & 176.77 & 0.46 \\
\hline Average & 11.77 & 8.17 & 8.87 & 149.99 & 0.49 \\
\hline$\pm \mathrm{SD}$ & 2.44 & 0.26 & 2.01 & 10.73 & 0.27 \\
\hline
\end{tabular}

747 
749 Table 3 Heavy metal average concentration (ug/L) in water sample of Fenghe river 750 basin and the reference value in water (ug/L).

\begin{tabular}{|c|c|c|c|c|c|c|c|c|c|c|c|}
\hline Sites & $\mathrm{Mn}$ & $\mathrm{Fe}$ & $\mathrm{Cr}$ & $\overline{\mathrm{Ni}}$ & $\mathrm{Cu}$ & $\overline{Z n}$ & $\overline{\mathrm{Cd}}$ & $\mathrm{Pb}$ & As & $\mathrm{Ti}$ & $\mathrm{Sr}$ \\
\hline$\overline{F Y}$ & 0.80 & 7.29 & 6.23 & 0.75 & 1.54 & 10.72 & 0.10 & 0.75 & 0.20 & 0.98 & 54.12 \\
\hline GGY & 4.41 & 34.29 & 6.17 & 0.78 & 1.40 & 11.06 & 0.03 & 0.70 & 0.43 & 1.17 & 104.28 \\
\hline TPY & 239.80 & 269.15 & 7.24 & 3.95 & 1.93 & 11.26 & 0.05 & 1.51 & 0.81 & 8.54 & 281.75 \\
\hline YRF & 99.47 & 227.15 & 7.53 & 2.25 & 2.29 & 19.86 & 0.05 & 1.25 & 2.66 & 4.56 & 262.50 \\
\hline FHK & 134.70 & 175.20 & 7.56 & 3.03 & 2.92 & 8.47 & 0.04 & 0.93 & 1.79 & 3.32 & 322.85 \\
\hline QDZ & 119.15 & 250.15 & 7.53 & 2.29 & 2.11 & 7.34 & 0.03 & 0.76 & 2.66 & 4.02 & 311.80 \\
\hline YJQ & 47.85 & 118.70 & 6.69 & 2.08 & 2.13 & 12.81 & 0.03 & 0.91 & 2.48 & 2.42 & 320.80 \\
\hline SLQ & 20.38 & 70.78 & 7.14 & 1.85 & 2.26 & 15.50 & 0.03 & 0.99 & 2.00 & 1.71 & 283.50 \\
\hline Average & 83.32 & 144.09 & 7.01 & 2.12 & 2.07 & 12.13 & 0.04 & 0.98 & 1.63 & 3.34 & 242.70 \\
\hline$\pm \mathrm{SD}$ & 76.59 & 94.57 & 0.54 & 1.00 & 0.44 & 3.74 & 0.02 & 0.26 & 0.95 & 2.31 & 97.21 \\
\hline $\begin{array}{l}\text { GB3838-2002 } \\
\text { limit value(1)* }\end{array}$ & 10 & 300 & 10 & --- & 10 & 50 & 1 & 10 & 50 & --- & --- \\
\hline $\mathrm{WHO}(2004)^{* *}$ & 300 & 1000 & 5 & 70 & 2000 & 5000 & 3 & 10 & 10 & --- & --- \\
\hline $\begin{array}{c}\text { CMC, } \\
\text { acute*** }\end{array}$ & --- & --- & 16 & 470 & --- & 120 & 1.8 & 65 & 340 & --- & --- \\
\hline $\begin{array}{c}\text { CMC, } \\
\text { chronic**** }\end{array}$ & --- & 1000 & 11 & 52 & --- & 120 & 0.72 & 2.5 & 150 & --- & --- \\
\hline
\end{tabular}

\footnotetext{
$751 *$ GB3838-2002, Environmental Quality Standard for Surface Water (GB3838-2002) (2002) China.

$752 * *$ WHO (2004), Guidelines for Drinking Water Quality, third ed. World Health Organization, Geneva.

$753 * *$ CMC, acute (Criterion maximum concentration in freshwater for National Recommended

754 Aquatic Life Criteria) https://www.epa.gov/(EPA 2009)

$755{ }^{* * * *} \mathrm{CMC}$, chronic (Criterion continuous concentration in freshwater for National Recommended

756 Aquatic Life Criteria) https://www.epa.gov/ (EPA 2009) 
758 Table 4 Heavy metal concentration $(\mathrm{mg} / \mathrm{kg})$ in sediment sample of Fenghe river basin 759 and the reference background value in water $(\mathrm{mg} / \mathrm{kg})$.

760

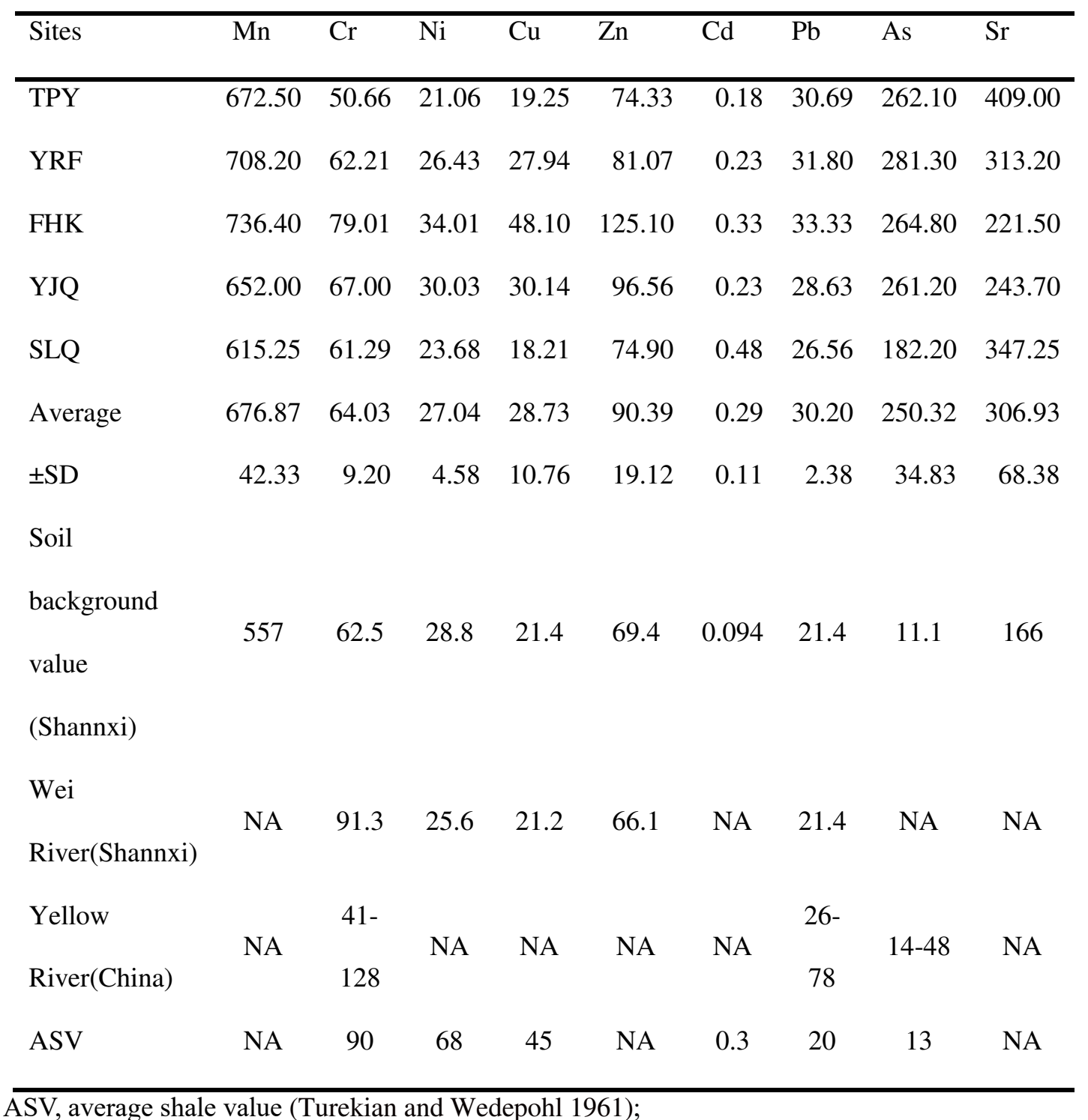

761 ASV, average shale value (Turekian and Wedepohl 1961); 
Table 5 Pearson Correlation matrix between heavy metal concentrations in water and sediment

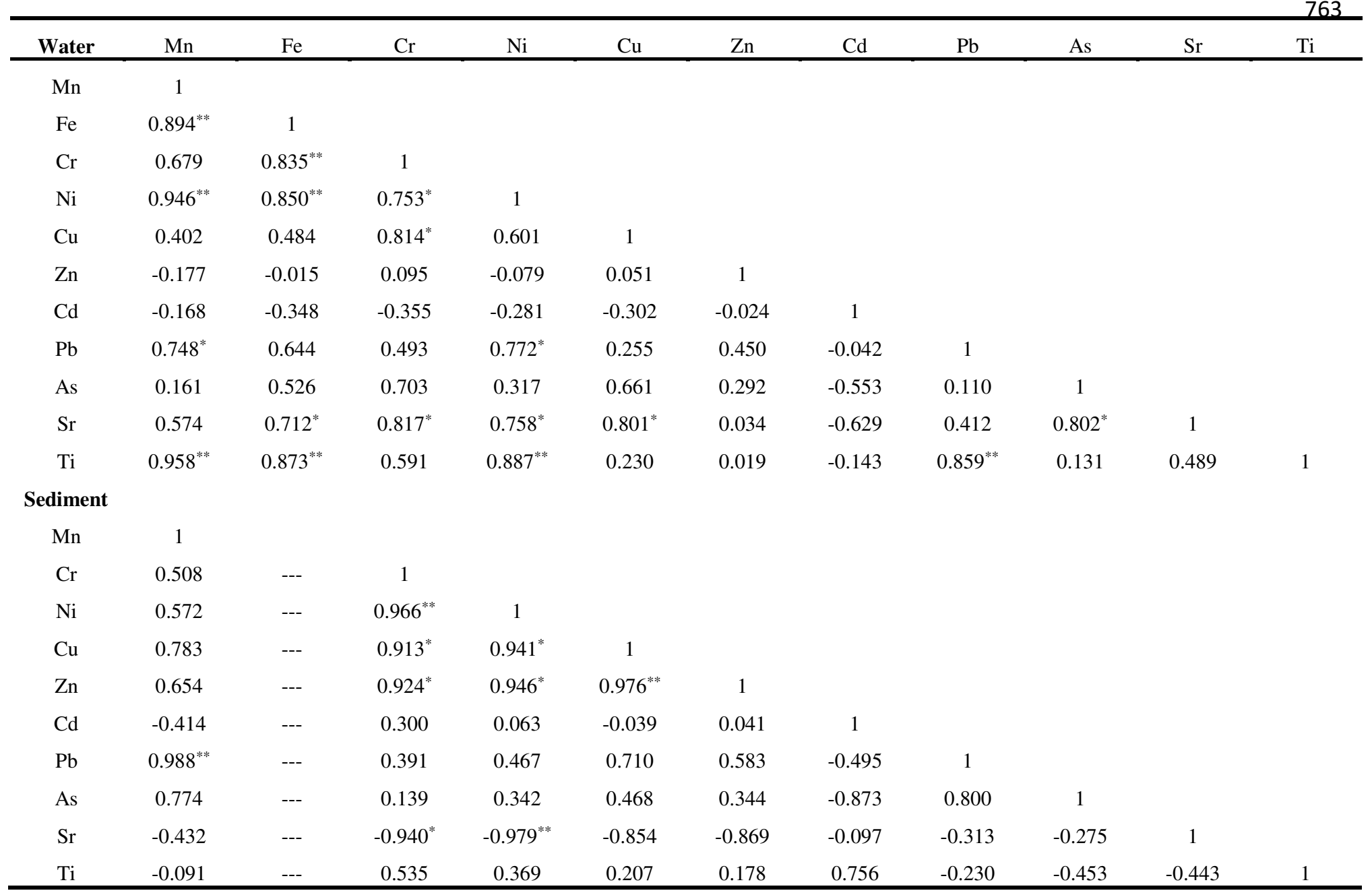

Significant to probability level 0.05 .

** Significant to probability level 0.01 . 
Table 6 Total interpretation variance and rotation component matrix of the principal components/factors of the Fenghe river in water and sediment samples

\begin{tabular}{|c|c|c|c|c|c|}
\hline \multirow{2}{*}{ Parameters } & \multicolumn{3}{|c|}{ Water } & \multicolumn{2}{|c|}{ Sediment } \\
\hline & $\overline{\mathrm{PC} 1}$ & $\overline{\mathrm{PC} 2}$ & $\overline{\mathrm{PC} 3}$ & $\overline{\mathrm{PC} 1}$ & $\mathrm{PC} 2$ \\
\hline $\mathrm{Mn}$ & 0.966 & 0.185 & -0.170 & 0.616 & 0.691 \\
\hline $\mathrm{Fe}$ & 0.819 & 0.467 & -0.032 & --- & --- \\
\hline $\mathrm{Cr}$ & 0.575 & 0.727 & 0.058 & 0.991 & -0.129 \\
\hline $\mathrm{Ni}$ & 0.899 & 0.378 & -0.081 & 0.978 & 0.063 \\
\hline $\mathrm{Cu}$ & 0.269 & 0.796 & 0.003 & 0.954 & 0.271 \\
\hline $\mathrm{Zn}$ & -0.027 & 0.077 & 0.994 & 0.944 & 0.169 \\
\hline $\mathrm{Cd}$ & -0.014 & -0.698 & 0.064 & 0.189 & -0.921 \\
\hline $\mathrm{Pb}$ & 0.861 & 0.011 & 0.475 & 0.507 & 0.771 \\
\hline As & 0.032 & 0.918 & 0.235 & 0.264 & 0.924 \\
\hline $\mathrm{Sr}$ & 0.436 & 0.866 & -0.011 & -0.936 & 0.043 \\
\hline $\mathrm{Ti}$ & 0.982 & 0.071 & 0.037 & 0.468 & -0.719 \\
\hline Eigenvalue & 4.713 & 3.648 & 1.315 & 5.576 & 3.414 \\
\hline$\%$ of total & 42.848 & 33.165 & 11.953 & 55.760 & 34.144 \\
\hline variance & & & & & \\
\hline Cumulative $\%$ & 42.848 & 76.013 & 87.966 & 55.760 & 89.904 \\
\hline
\end{tabular}

Extration method: principal component analysis.

771 Factor loadings: Varimax normalized (value rendered in italics are loadings $>0.700$ ) 
774 Figure 1 The Map of the study area with sampling locations.

775 Figure 2 The comprehensive quality index (WQI) and Nemero index (Pn) of heavy 776 metal in water in Fenghe river basin.

777 Figure 3 The geological accumulation index (I-geo) and potential ecological risk 778 index (RI) of heavy metal in sediment in Fenghe River Basin.

779 Figure 4 Dendrogram of cluster analysis amongst the parameters of Fenghe river in 780 water(a) and in sediment(b) samples.

781 Figure 5 Results of PMF source apportionment modeling for heavy metals in (a)

782 water and (b) sediment in the Fenghe River, Shannxi.

783 Figure 6 The average factor contribution ration for heavy metals in (a) water and (b) 784 sediment in the Fenghe River, Shannxi. 


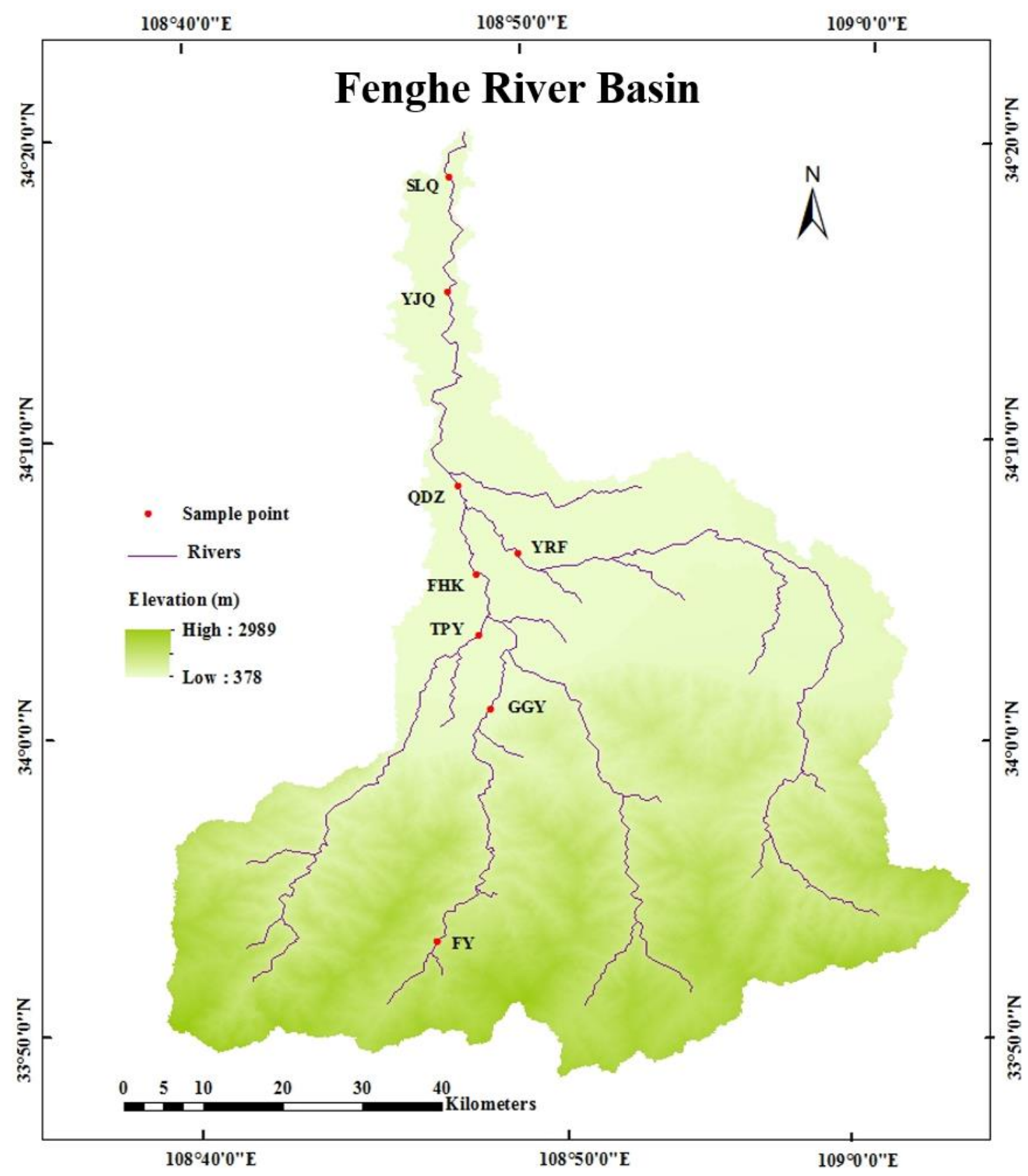

787

Figure1 The Map of the study area with sampling locations. 


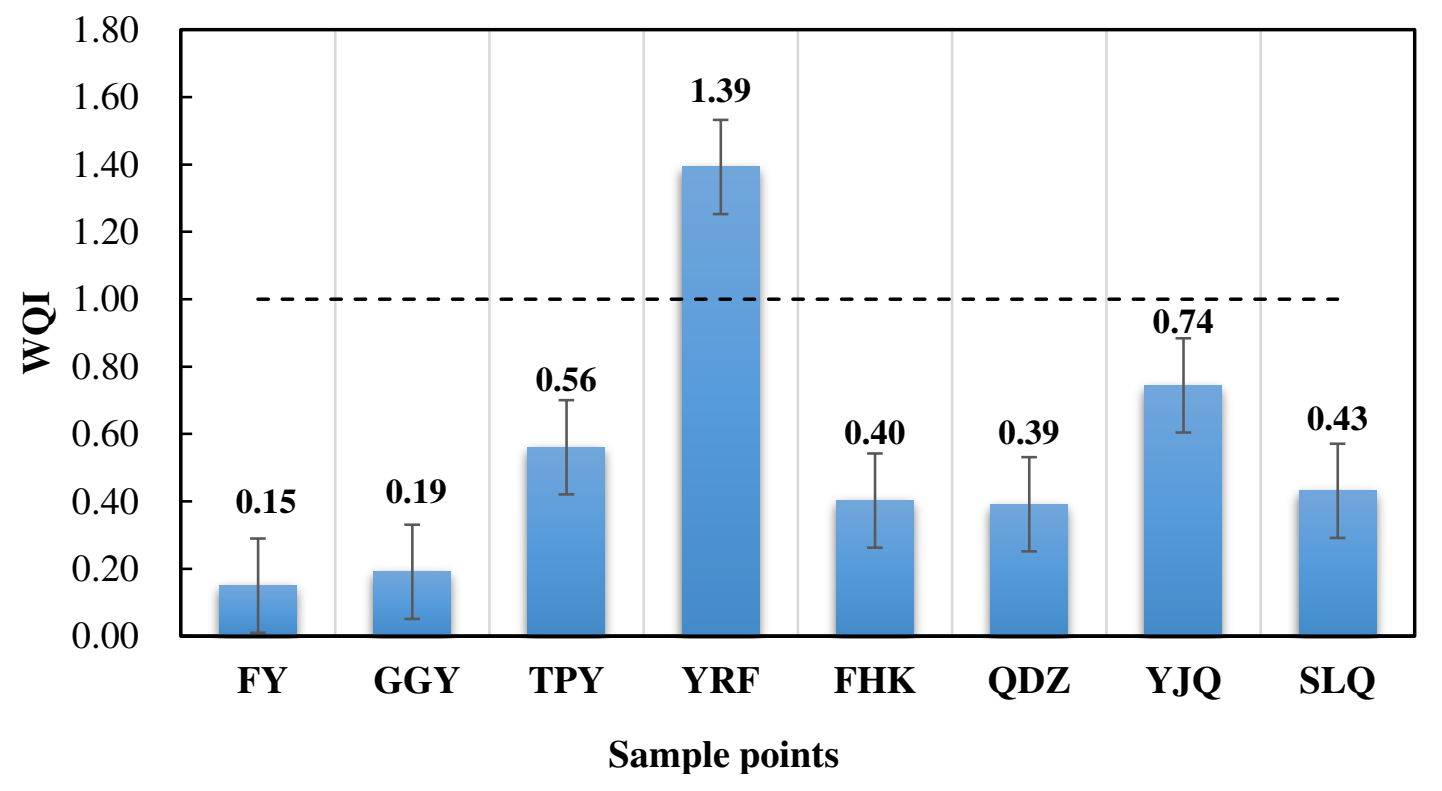

790

(a)

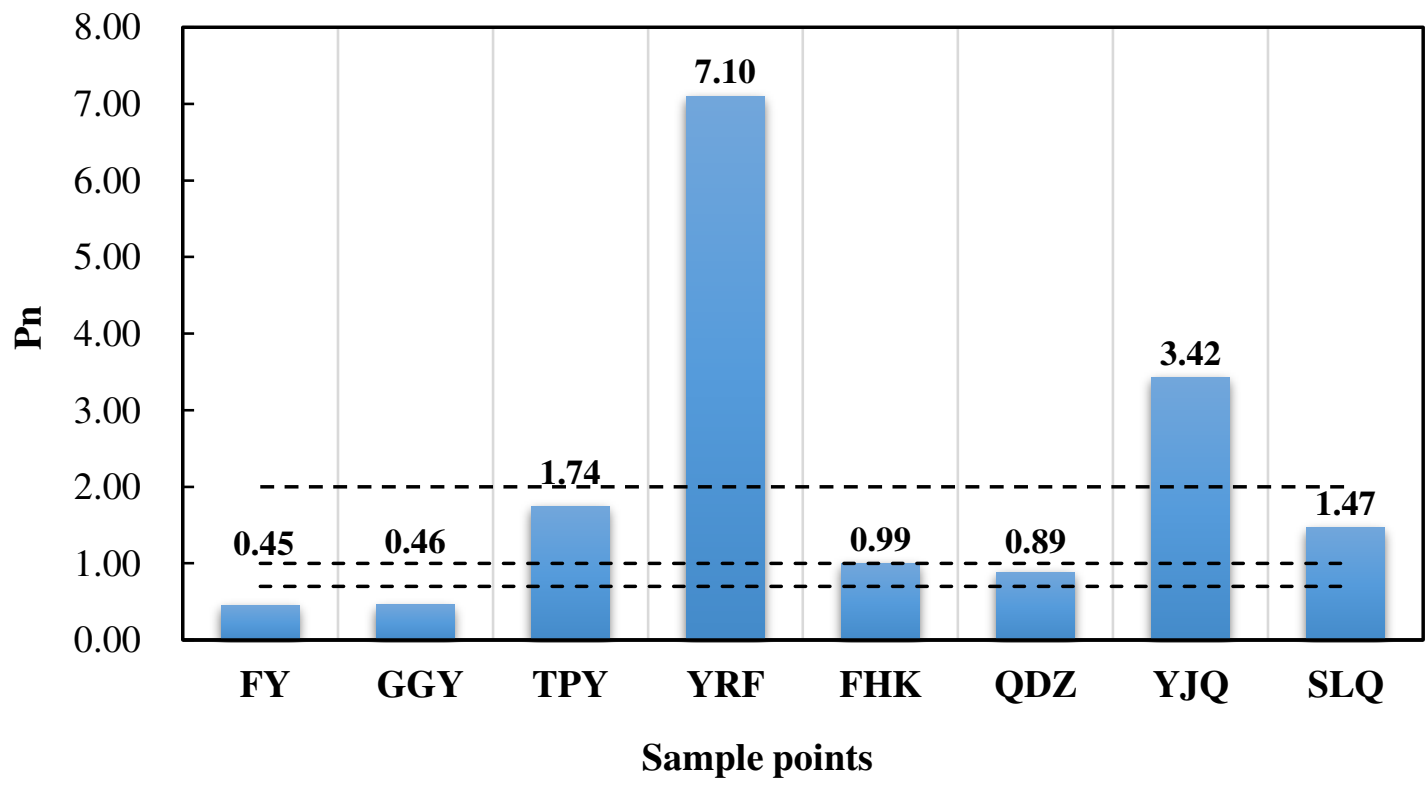

(b)

793 Figure 2 The comprehensive quality index (WQI) and Nemero index (Pn) of heavy metal in water in Fenghe river basin. 
795

796

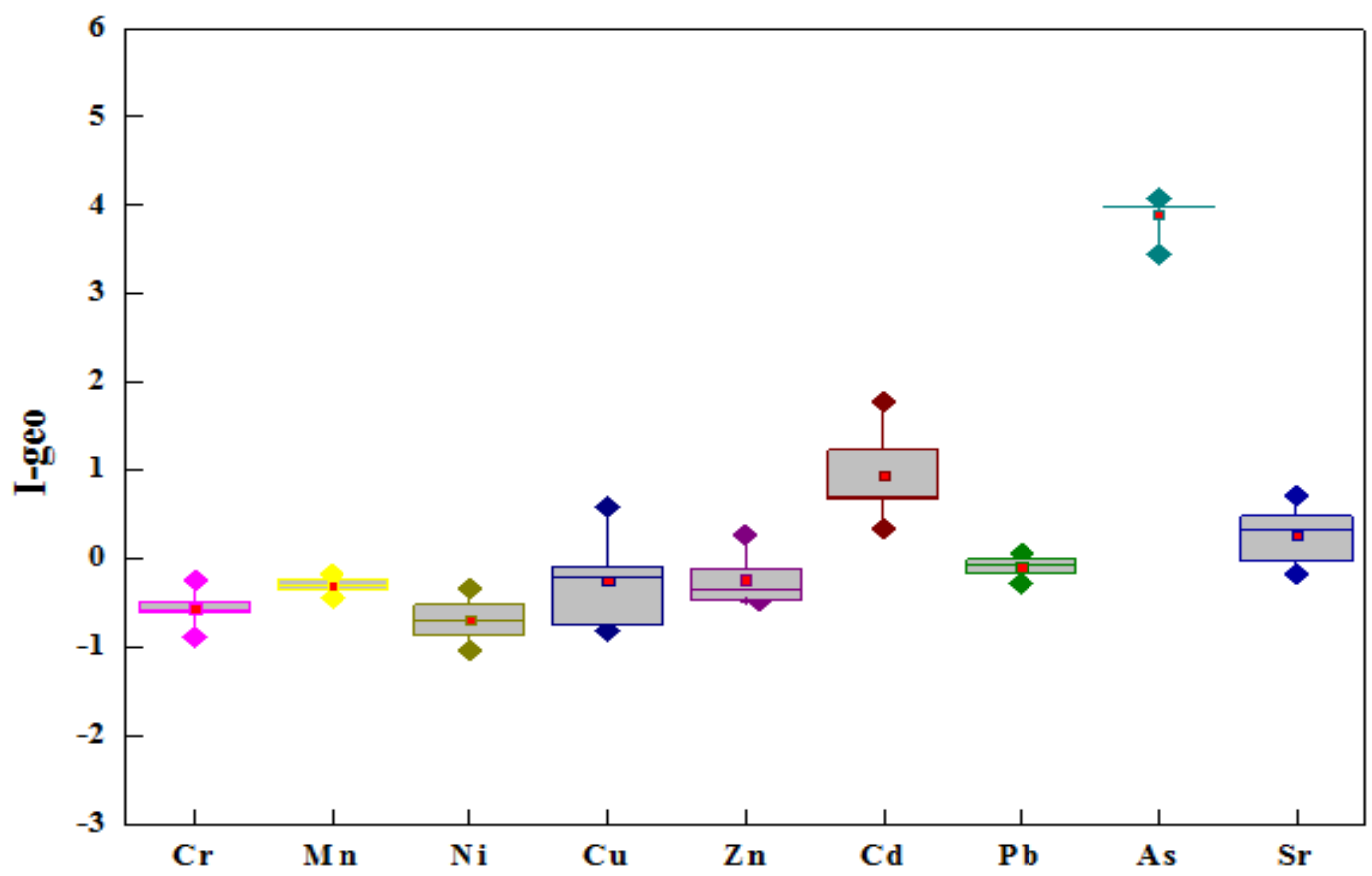

(a)

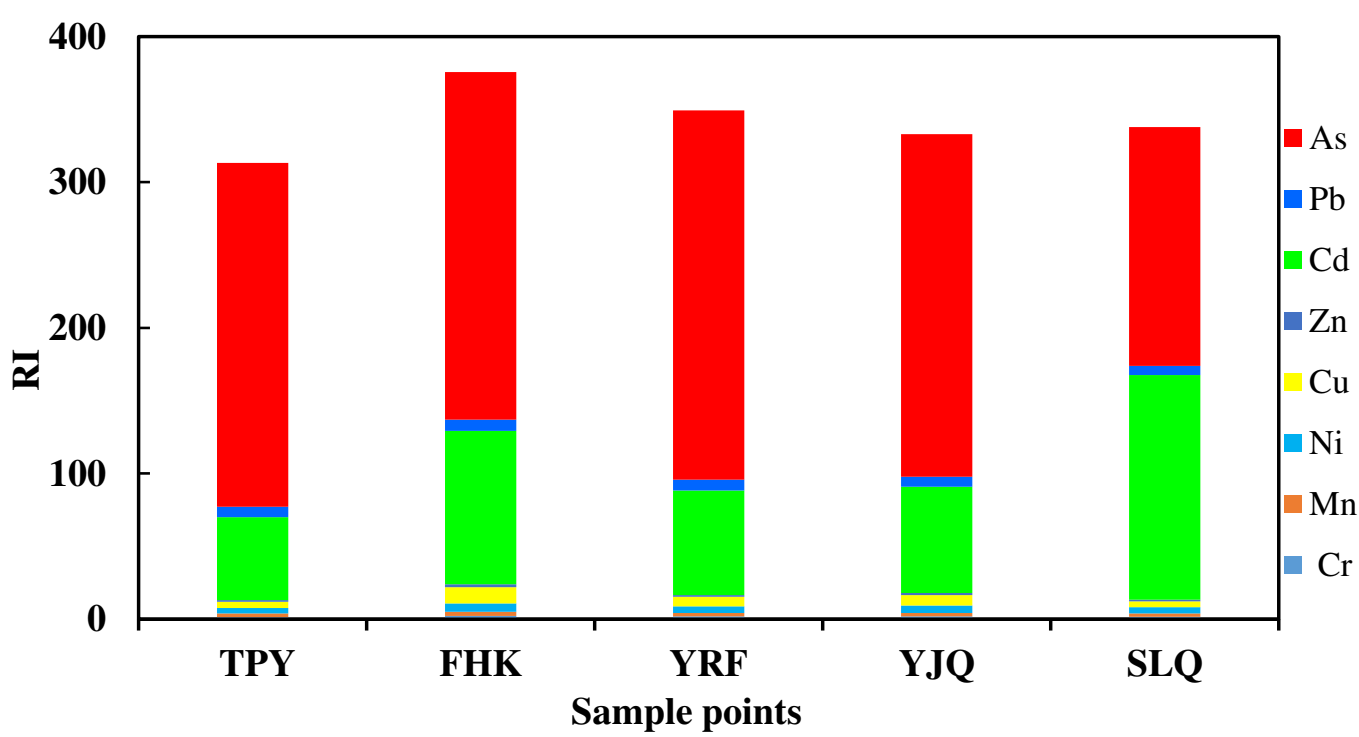

797

798

(b)

799 Figure 3 The geological accumulation index (I-geo) and potential ecological risk

800 index (RI) of heavy metal in sediment in Fenghe River Basin. 


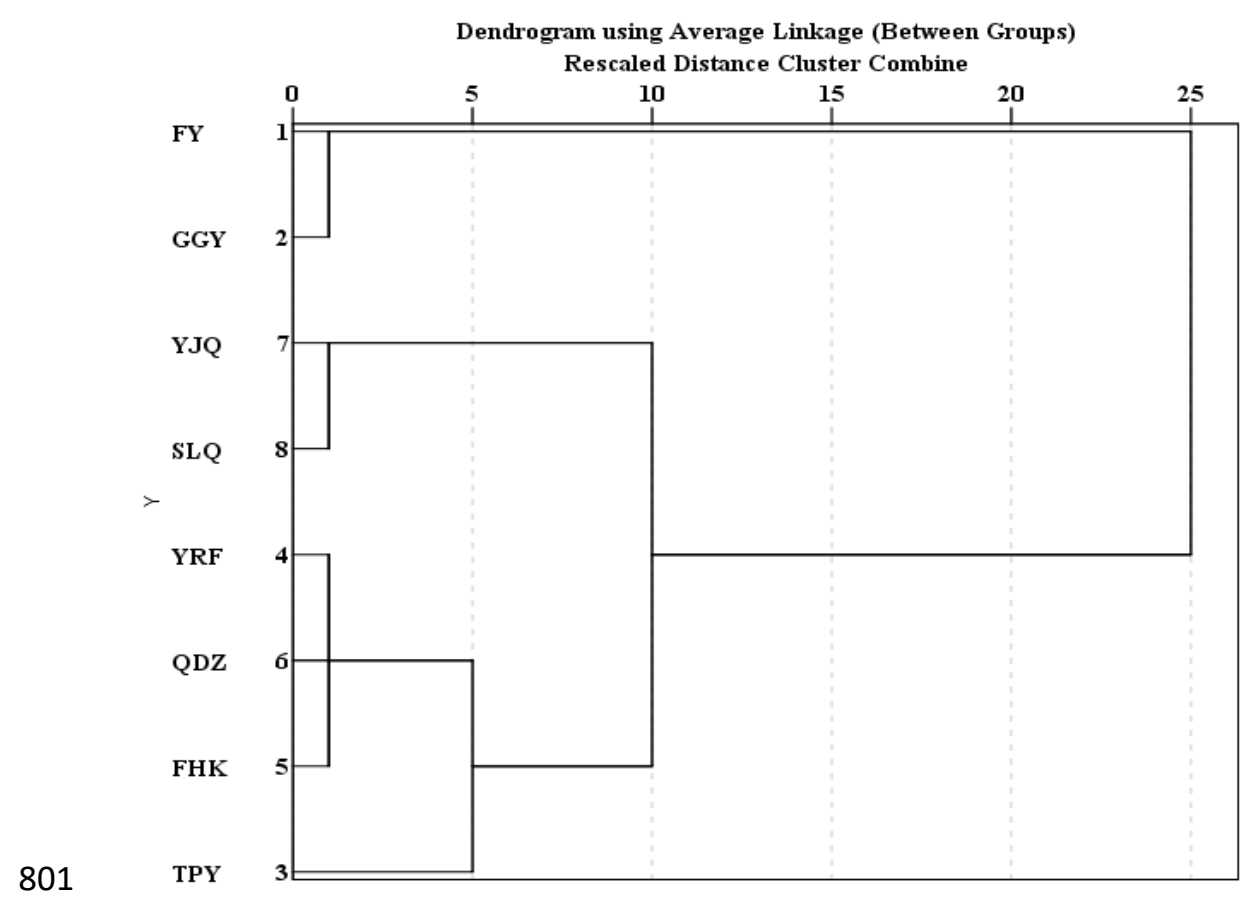

802

(a)

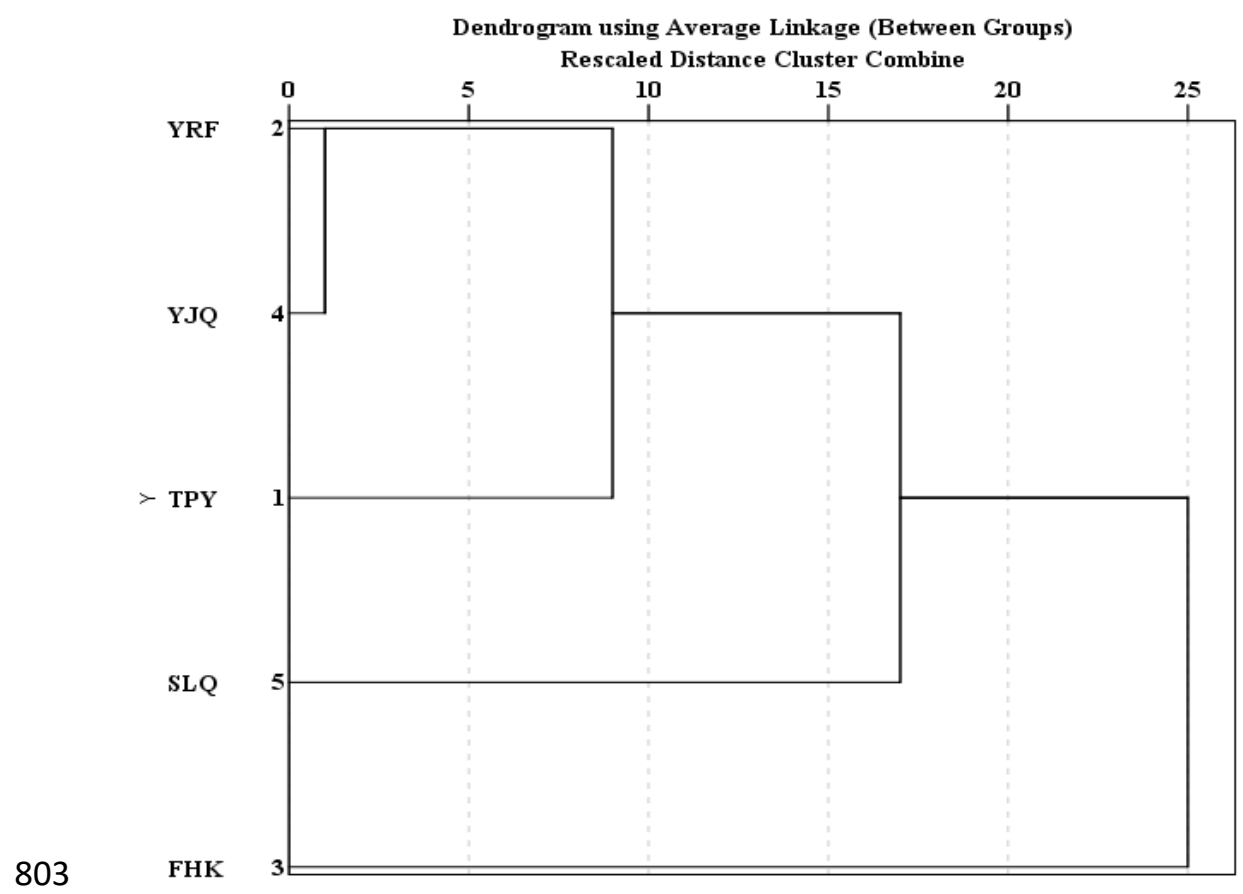

(b)

805 Figure 4 Dendrogram of cluster analysis amongst the parameters of Fenghe river in water(a) and in sediment(b) samples. 


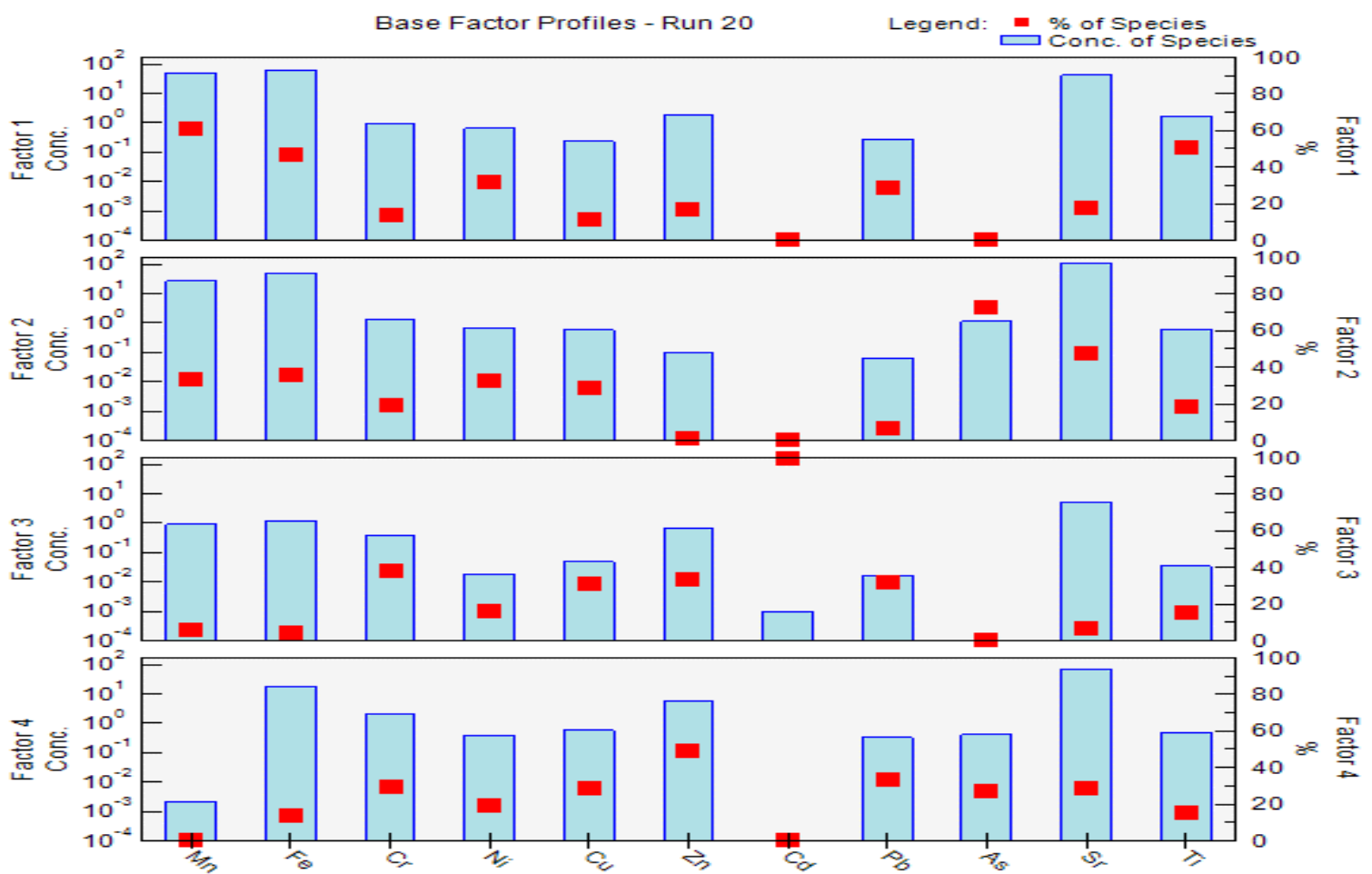

a) Water

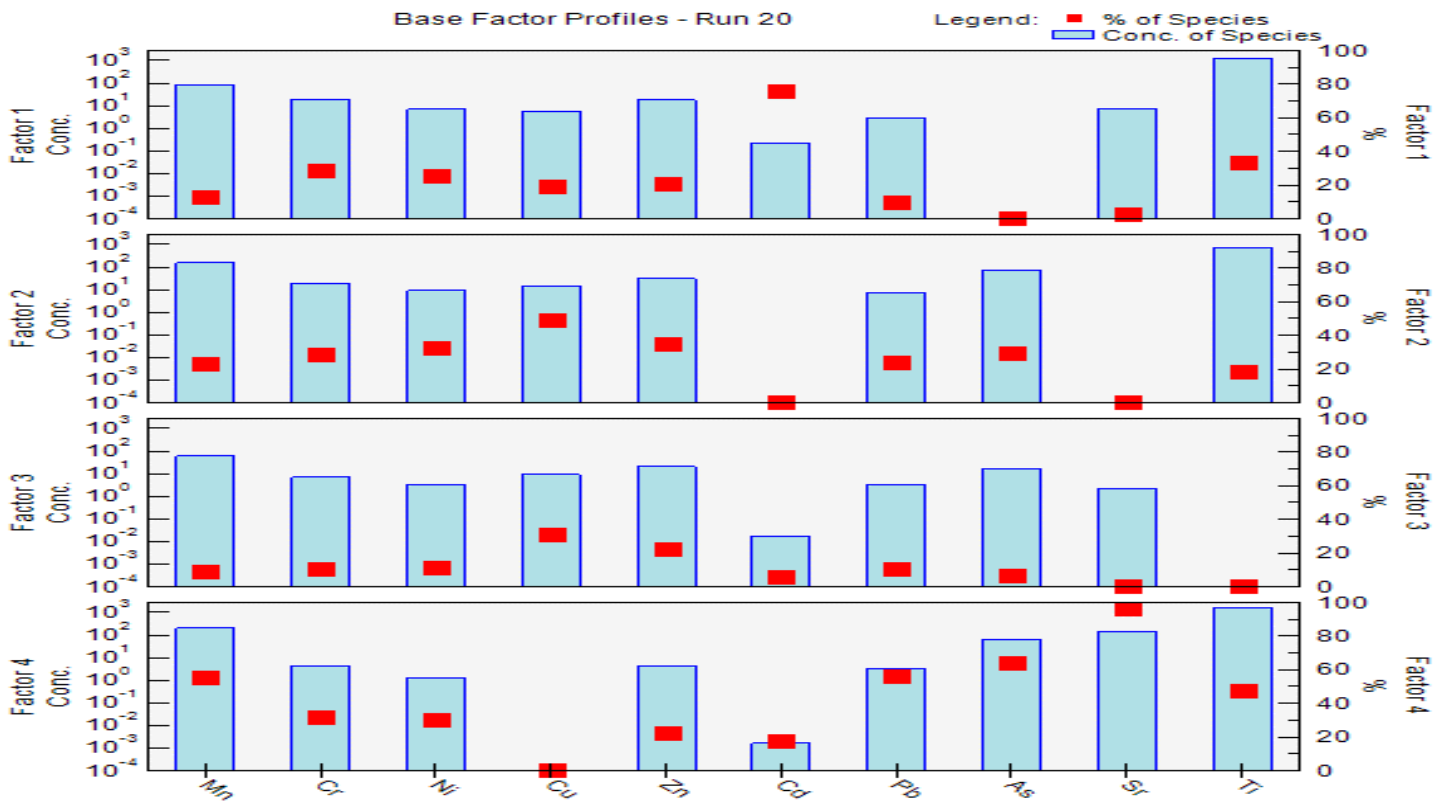

\section{b) Sediment}

811 Figure 5 Results of PMF source apportionment modeling for heavy metals in (a)

812 water and (b) sediment in the Fenghe River, Shannxi. 
813

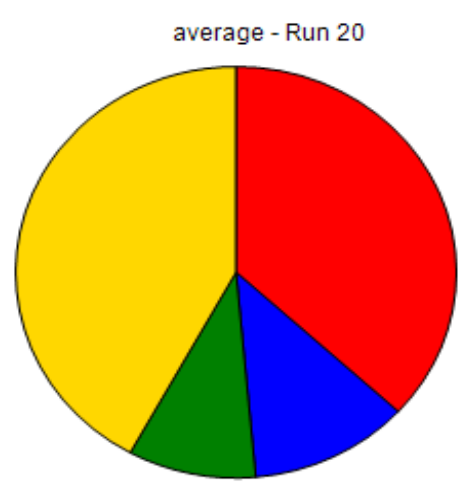

a) Water

815

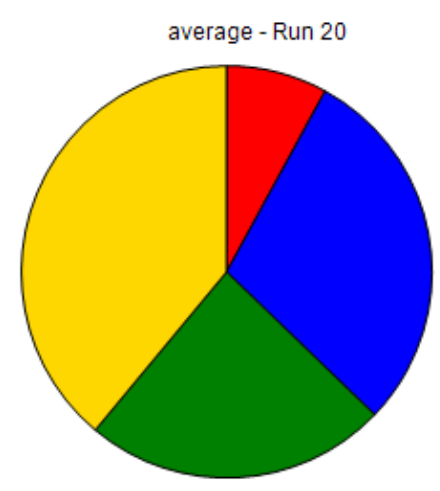

b) Sediment
Factor Contribution $>0.05 \%$

$\square$ Factor $1=16.75100(36.8 \%)$

— Factor $2=5.33270(11.7 \%)$

$\square$ Factor $3=4.27570(9.4 \%)$

$\square$ Factor $4=19.10400(42.0 \%)$
Factor Contribution $>0.05 \%$

$\square$ Factor $1=41.86200(8.0 \%)$

- Factor $2=153.93000(29.2 \%)$

$\square$ Factor $3=125.61000(23.9 \%)$

$\square$ Factor $4=204.94000(38.9 \%)$

817 Figure 6 The average factor contribution ration for heavy metals in (a) water and (b)

818 sediment in the Fenghe River, Shannxi. 


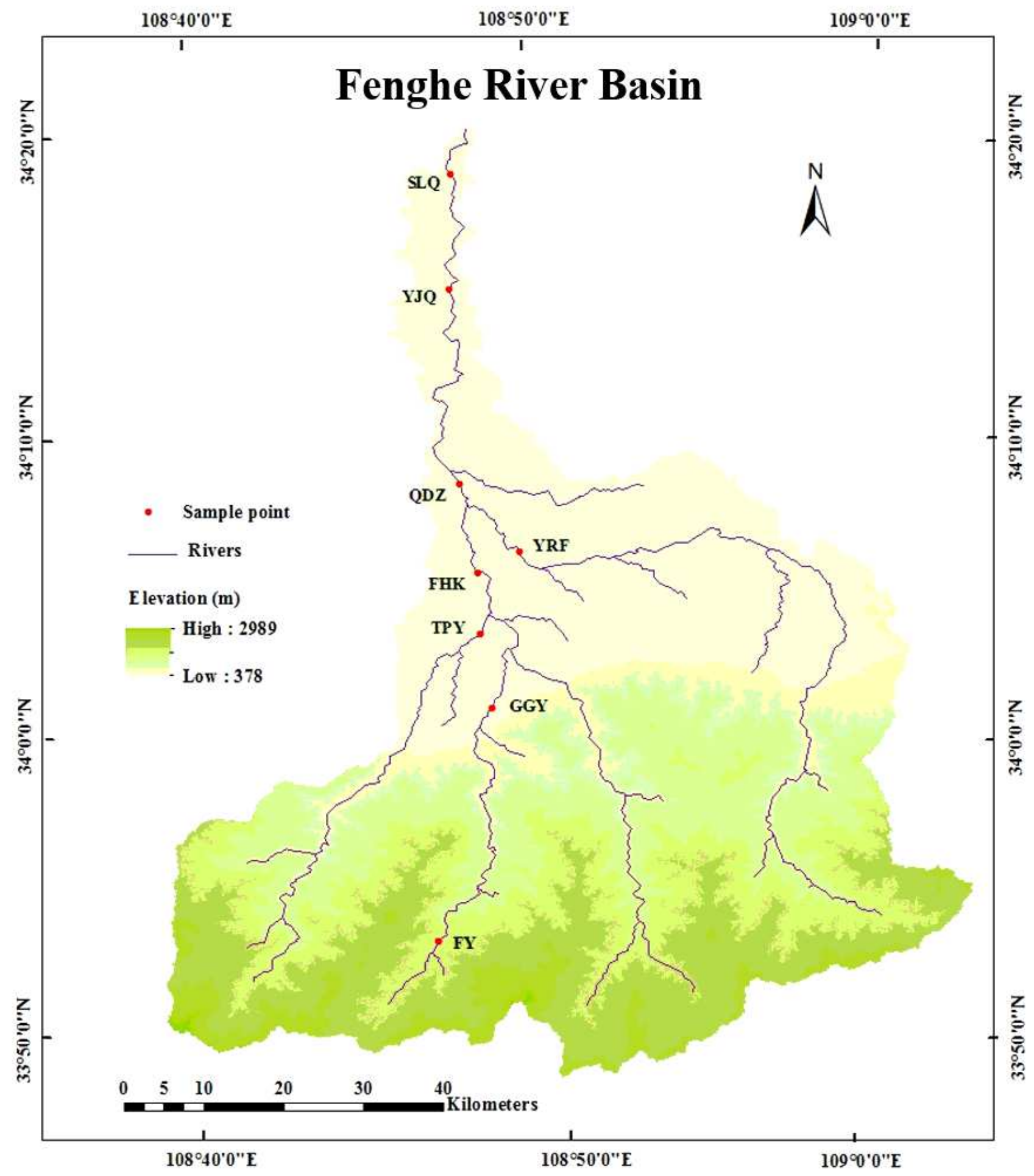

\section{Figure 1}

The Map of the study area with sampling locations. Note: The designations employed and the presentation of the material on this map do not imply the expression of any opinion whatsoever on the part of Research Square concerning the legal status of any country, territory, city or area or of its 
authorities, or concerning the delimitation of its frontiers or boundaries. This map has been provided by the authors.

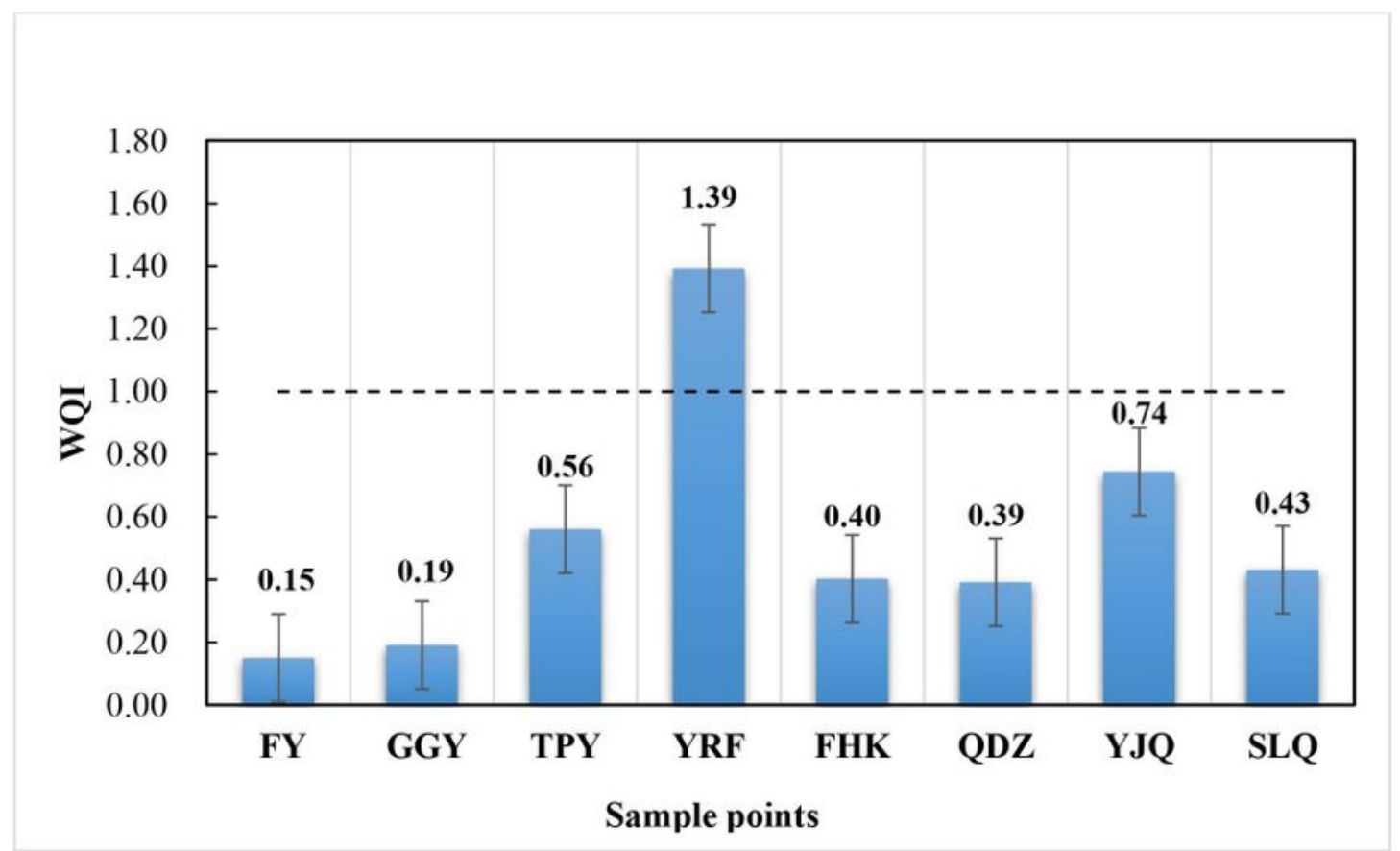

(a)

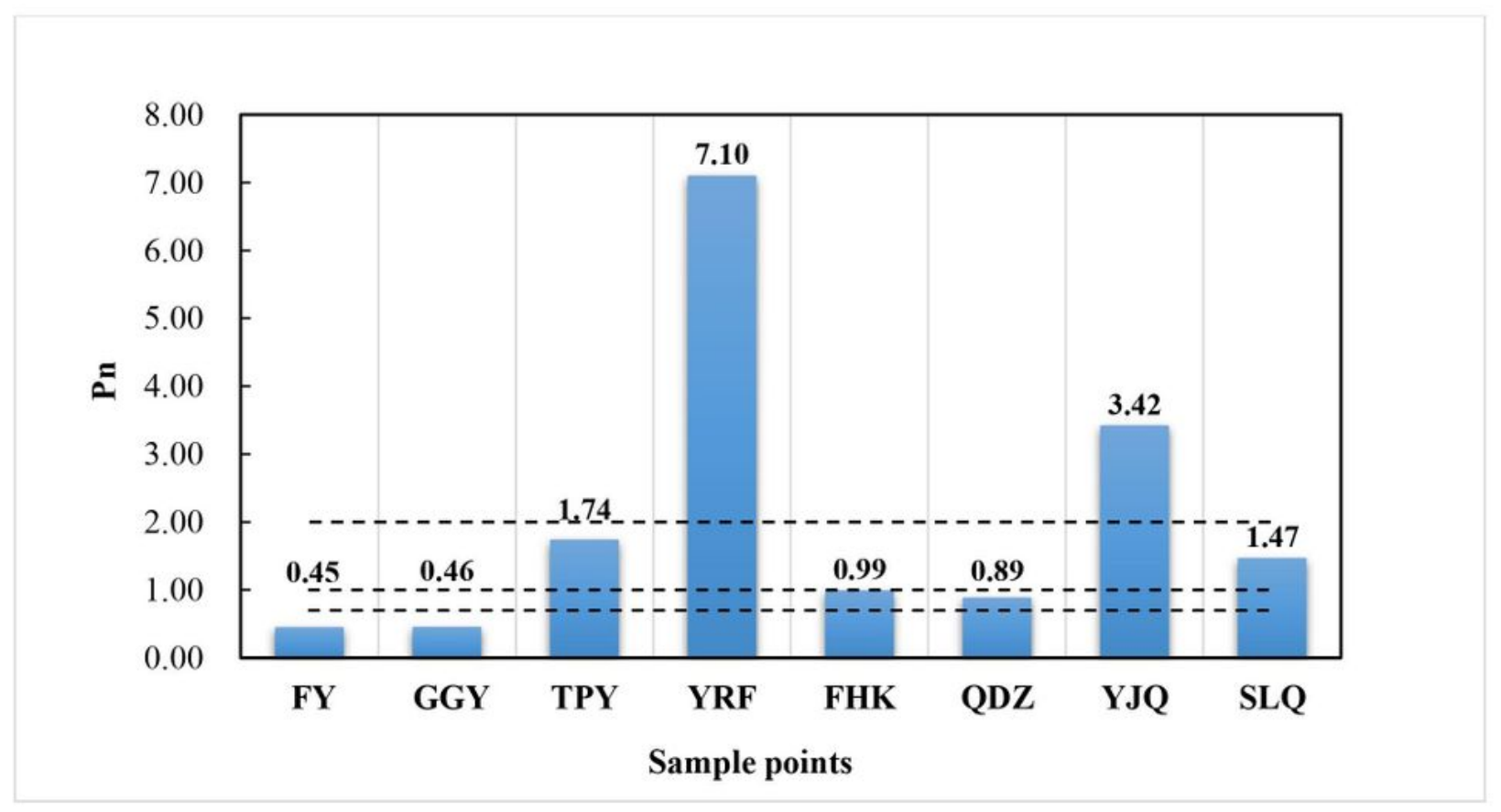

(b)

Figure 2

The comprehensive quality index (WQI) and Nemero index (Pn) of heavy metal in water in Fenghe river basin. 


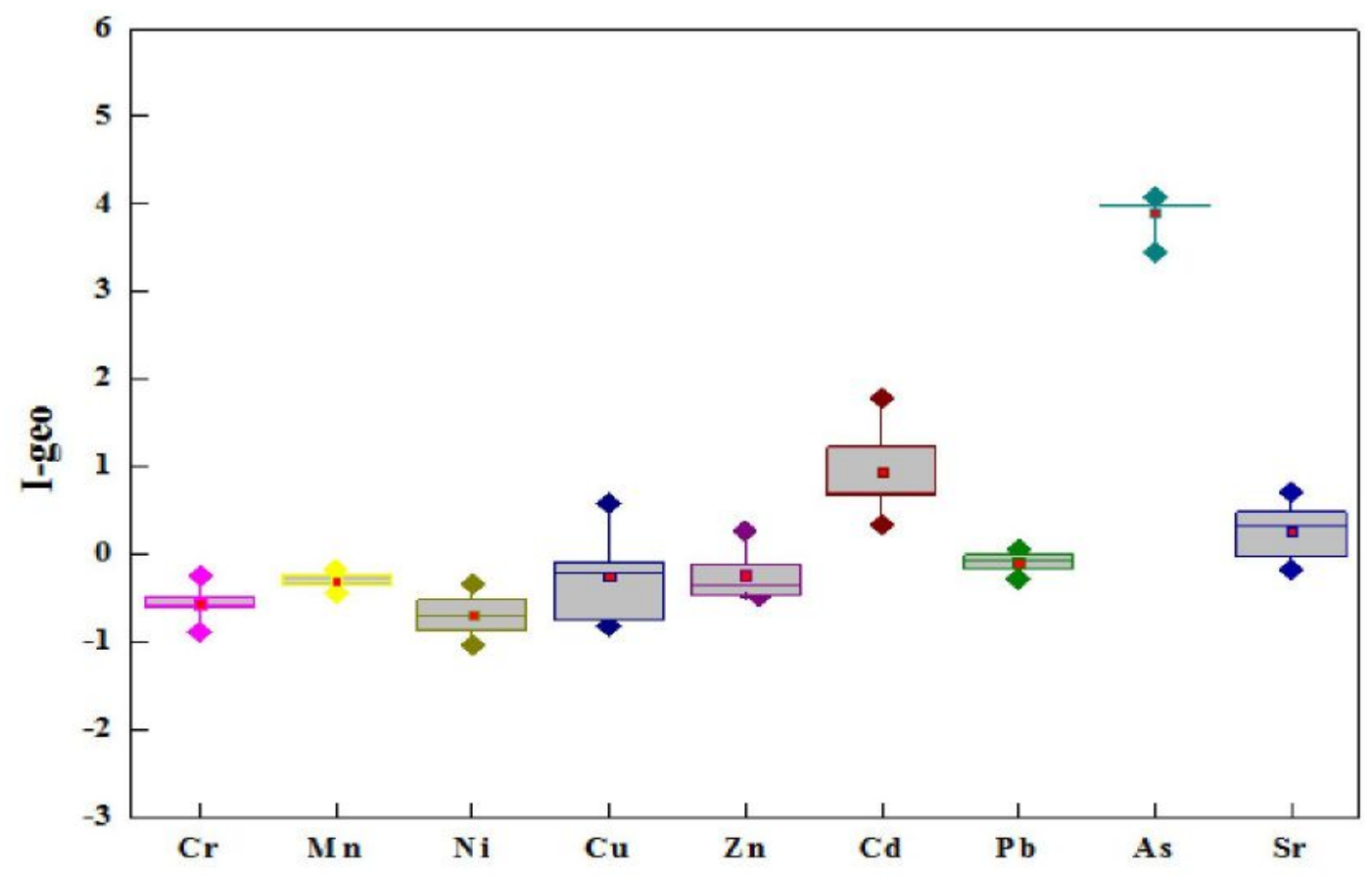

(a)

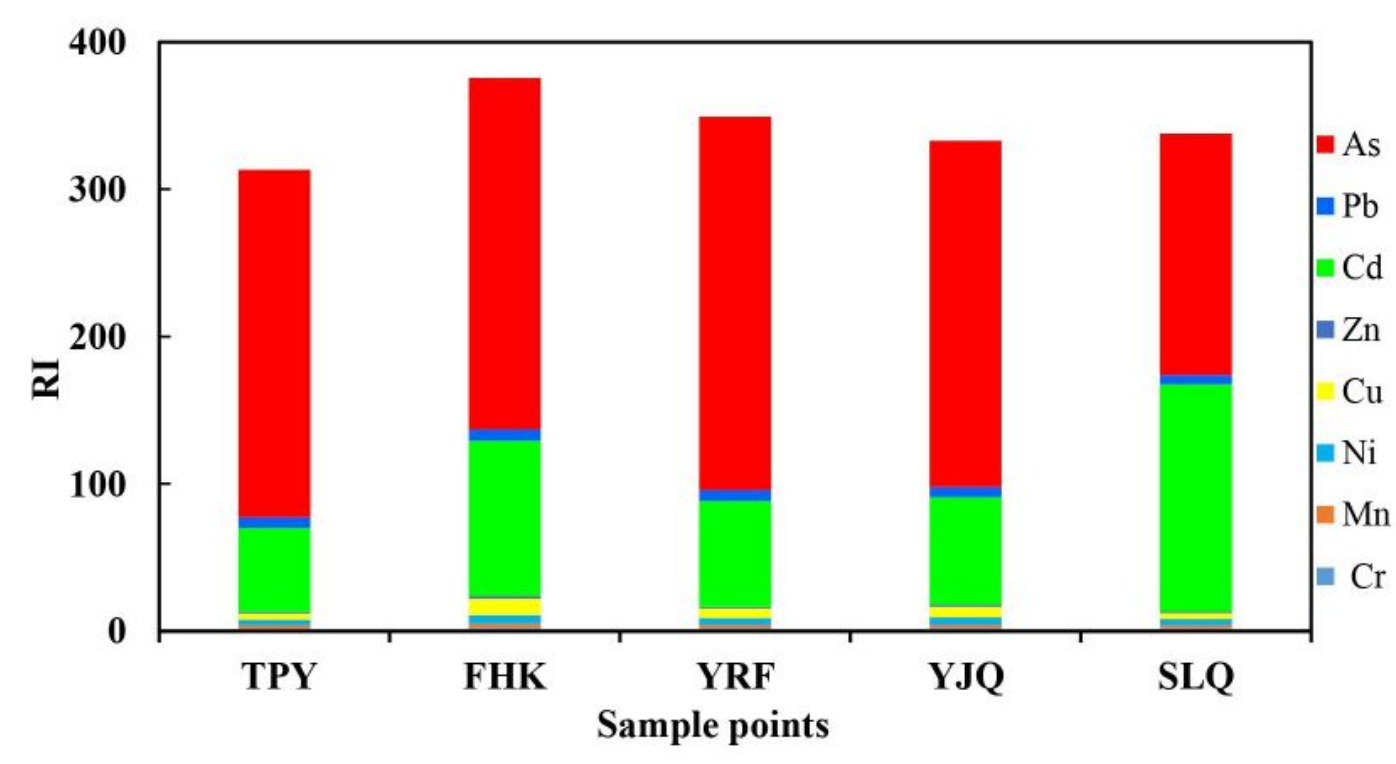

(b)

\section{Figure 3}

The geological accumulation index (I-geo) and potential ecological risk index (RI) of heavy metal in sediment in Fenghe River Basin. 


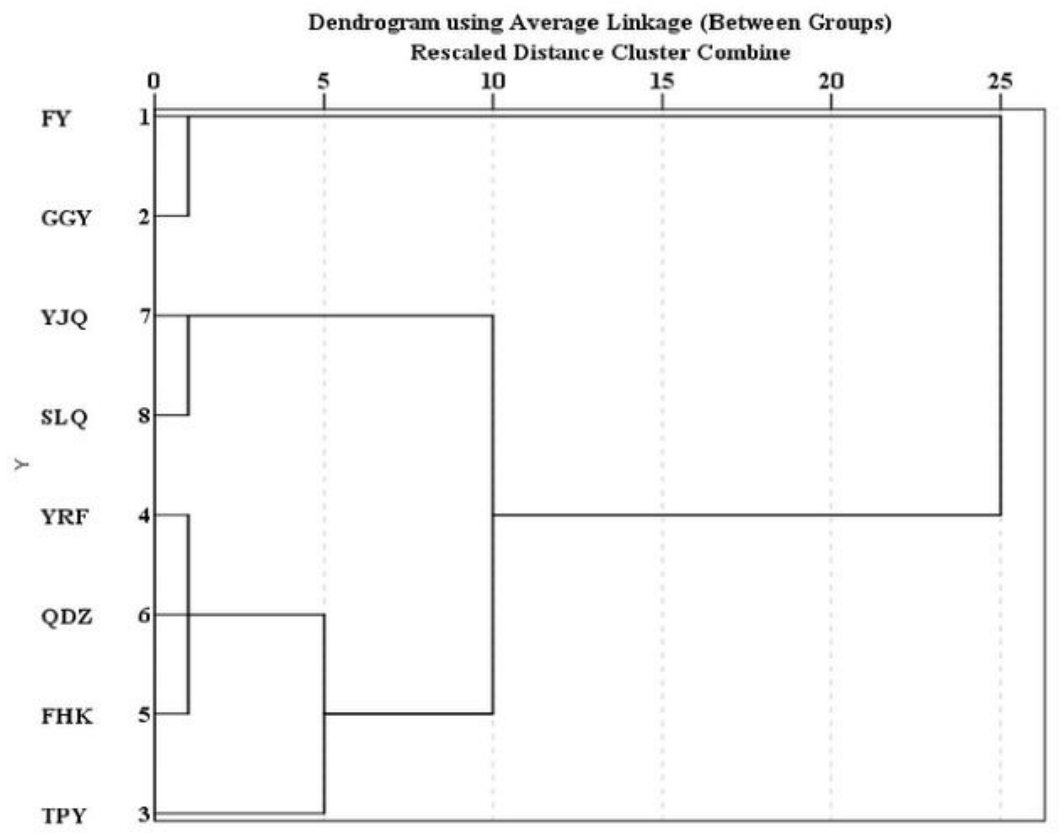

(a)

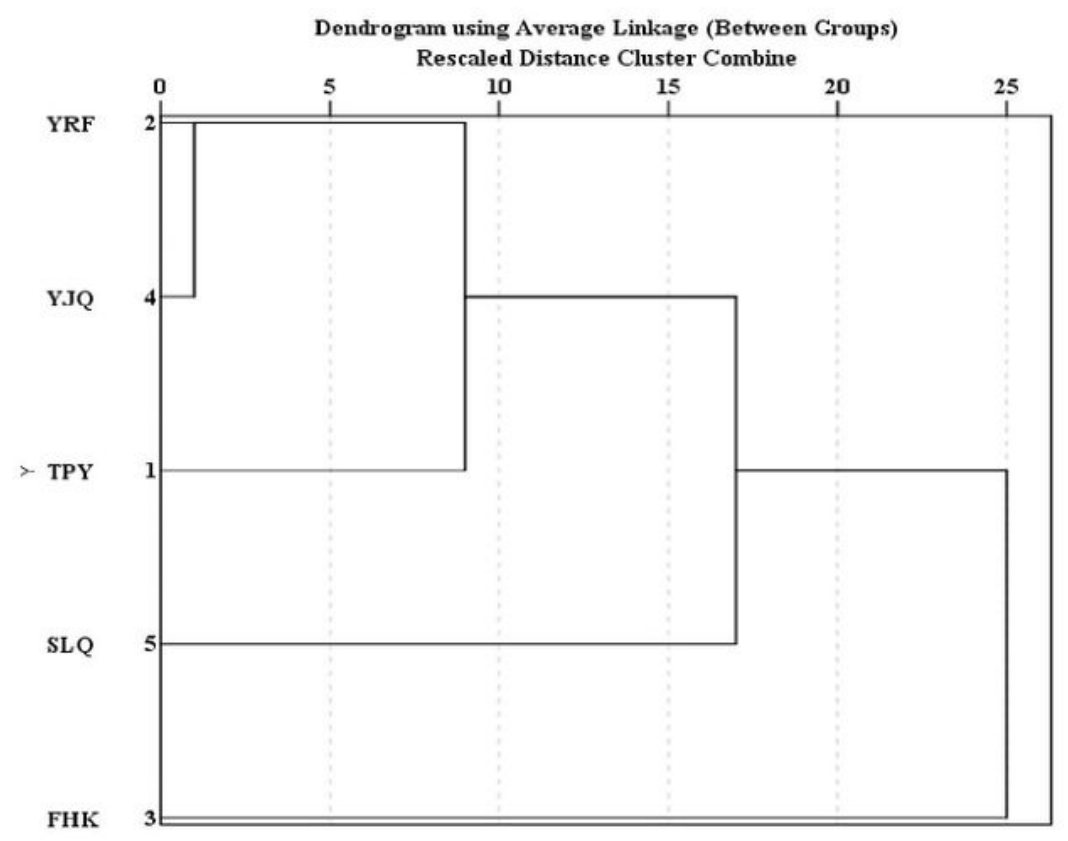

(b)

\section{Figure 4}

Dendrogram of cluster analysis amongst the parameters of Fenghe river in water(a) and in sediment(b) samples. 


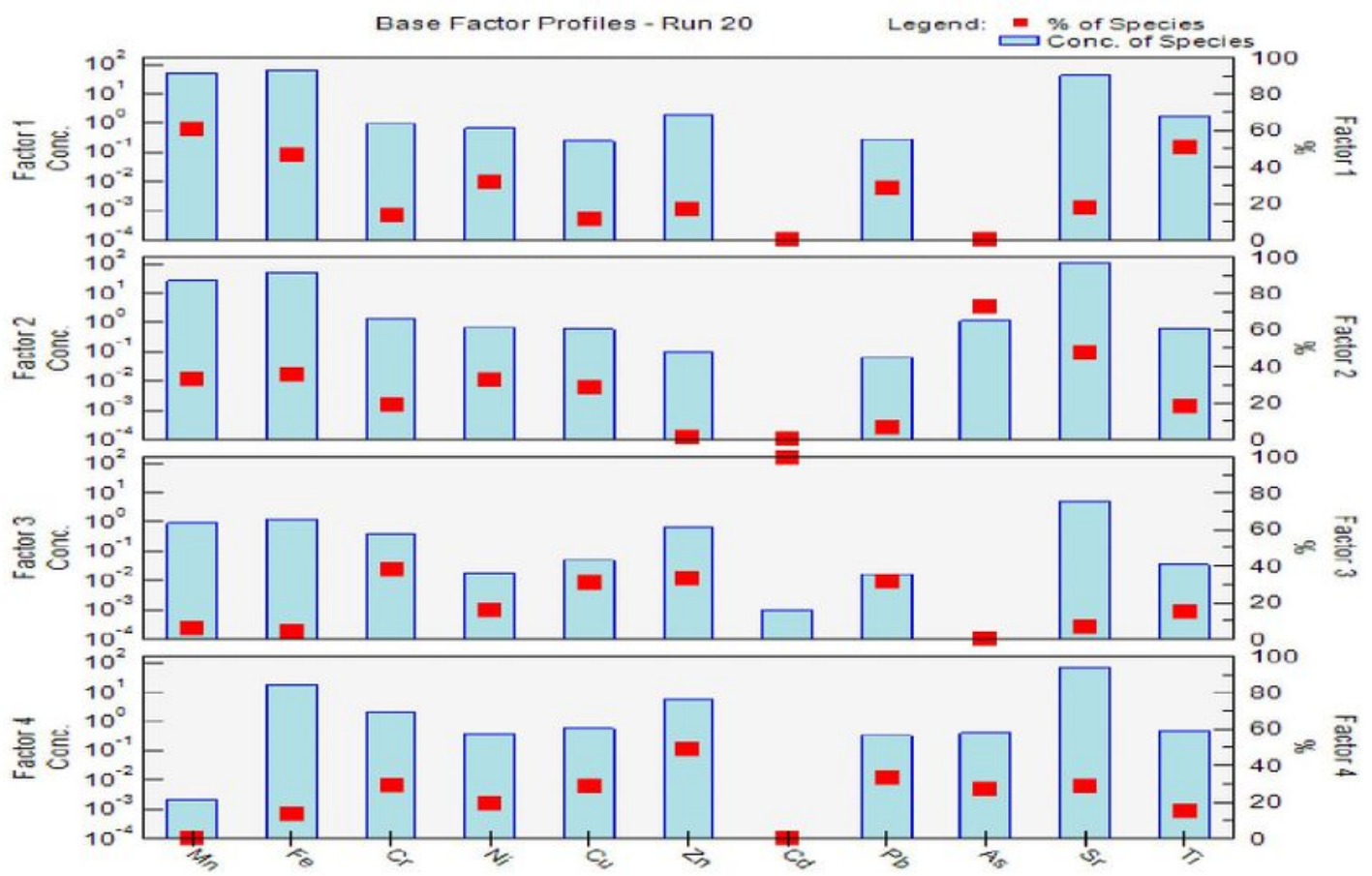

a) Water

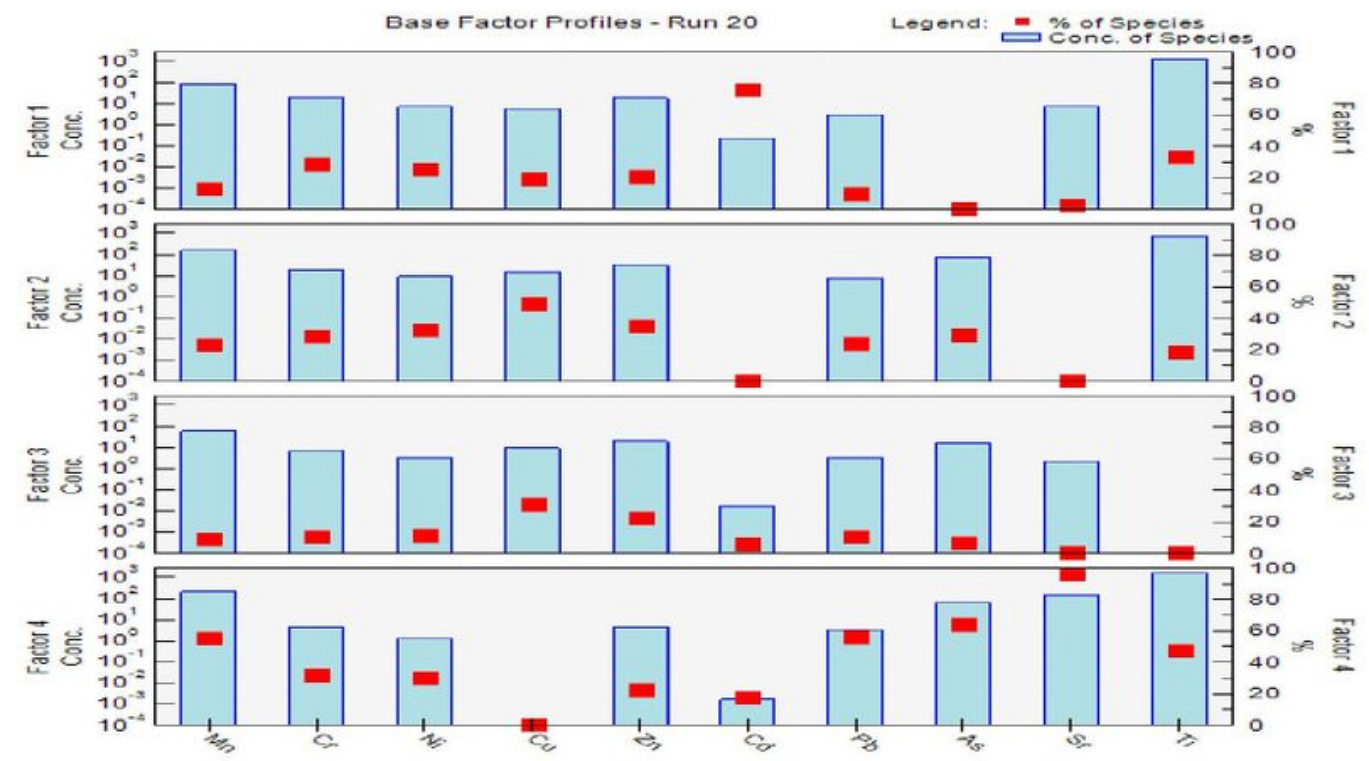

b) Sediment

\section{Figure 5}

Results of PMF source apportionment modeling for heavy metals in (a) water and (b) sediment in the Fenghe River, Shannxi. 

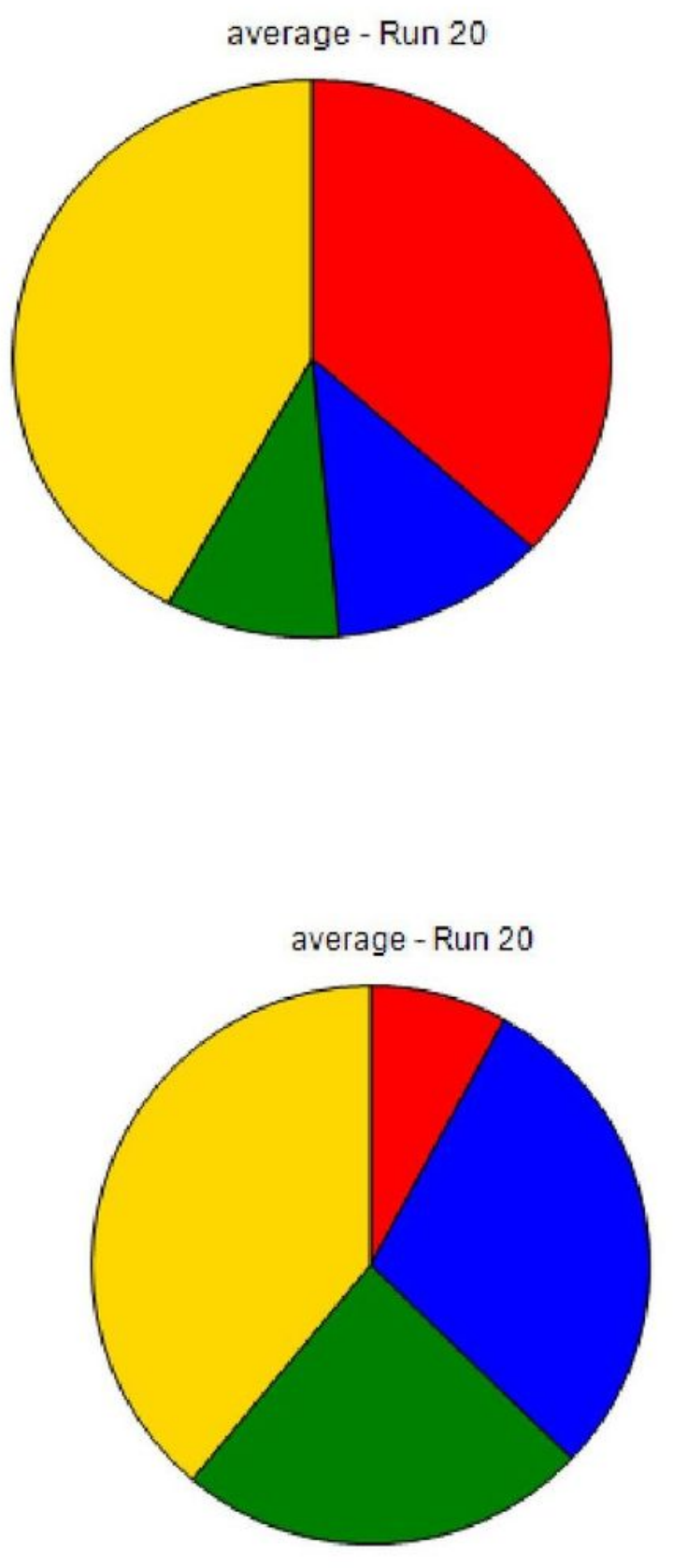

Factor Contribution $>0.05 \%$

$$
\begin{aligned}
& \square \text { Factor } 1=16.75100(36.8 \%) \\
& \text { Factor } 2=5.33270(11.7 \%) \\
& \square \text { Factor } 3=4.27570(9.4 \%) \\
& \square \text { Factor } 4=19.10400(42.0 \%)
\end{aligned}
$$

\section{a) Water}

\section{b) Sediment}

\section{Figure 6}

The average factor contribution ration for heavy metals in (a) water and (b) sediment in the Fenghe River, Shannxi. 